University of Nebraska - Lincoln

DigitalCommons@University of Nebraska - Lincoln

\title{
Holocene Environmental and Climatic Change in the Northern Great Plains as Recorded in the Geochemistry of Sediments in Pickerel Lake, South Dakota
}

Walter E. Dean

U.S. Geological Survey, Denver, CO, dean@usgs.gov

Antje Schwalb

GeoForschungsZentrum, Projektbereich 3.3, Telegrafenberg, D-14473 Potsdam, Germany

Follow this and additional works at: https://digitalcommons.unl.edu/usgsstaffpub

Part of the Earth Sciences Commons

Dean, Walter E. and Schwalb, Antje, "Holocene Environmental and Climatic Change in the Northern Great Plains as Recorded in the Geochemistry of Sediments in Pickerel Lake, South Dakota" (2000). USGS Staff -- Published Research. 323.

https://digitalcommons.unl.edu/usgsstaffpub/323

This Article is brought to you for free and open access by the US Geological Survey at DigitalCommons@University of Nebraska - Lincoln. It has been accepted for inclusion in USGS Staff -- Published Research by an authorized administrator of DigitalCommons@University of Nebraska - Lincoln. 


\title{
Holocene environmental and climatic change in the Northern Great Plains as recorded in the geochemistry of sediments in Pickerel Lake, South Dakota
}

\author{
Walter E. Dean ${ }^{\mathrm{a}, *}$, Antje Schwalb \\ ${ }^{a}$ U.S. Geological Survey, P.O. Box 25046, MS 980 Federal Center, Denver, CO 80225, USA \\ ${ }^{\mathrm{b}}$ GeoForschungsZentrum, Projektbereich 3.3, Telegrafenberg, D-14473 Potsdam, Germany
}

Received 15 January 2000; accepted 10 February 2000

\begin{abstract}
The sediments in Pickerel Lake, northeastern South Dakota, provide a continuous record of climatic and environmental change for the last 12000 yr. Sediments deposited between 12 and $6 \mathrm{ka}$ (radiocarbon) show extreme variations in composition, oxygen and carbon isotopic composition of bulk carbonate, carbon isotopic composition of organic matter, and magnetic susceptibility. These variations reflect changes in sources of moisture, regional vegetation types, precipitation-evaporation balance, ground- and surface-water influx, water residence time, erosion, lake productivity, water level, and water temperature. The total carbonate content of late Pleistocene sediments steadily increased from $<20 \%$ at the base of the core to as much as $80 \%$ in sediments deposited between 11 and $9 \mathrm{ka}$. By about $8 \mathrm{ka}$, the total carbonate content of the sediments had declined to about $40 \%$ where it remained with little variation for the past $8 \mathrm{kyr}$, suggesting relatively stable conditions. There are marked increases in values of $\delta^{13} \mathrm{C}$ and $\delta^{18} \mathrm{O}$ in bulk carbonate, and $\delta^{13} \mathrm{C}$ of organic matter, in sediments deposited between 10 and $6 \mathrm{ka}$ as evaporation increased, and the vegetation in the watershed changed from forest to prairie. This shift toward more ${ }^{18} \mathrm{O}$-enriched carbonate may also reflect a change in source or seasonality of precipitation. During this early Holocene interval the organic carbon (OC) content of the sediments remained relatively low $(2-3 \%)$, but then increased rapidly to $4.5 \%$ between 7 and $6 \mathrm{ka}$, reflecting the rapid transition to a prairie lake. The OC content fluctuates slightly between 4 and $6 \%$ in sediments deposited over the past $6 \mathrm{kyr}$. Like OC and total carbonate, most variables measured show little variation in the $13 \mathrm{~m}$ of sediment deposited over the past $6 \mathrm{kyr}$, particularly when compared with early Holocene variations. Although the magnetic susceptibility of this upper $13 \mathrm{~m}$ of sediment is generally low ( $<10$ SI units), the upper six meters of the section is marked by striking $1 \mathrm{~m}$ cycles (ca. $400-500 \mathrm{yr}$ periodicity) in susceptibility. These cycles are interpreted as being due to variations in the influx of eolian detrital-clastic material. Century-scale cyclic variations in different proxy variables for aridity and eolian activity from sediments deposited over the past $2000 \mathrm{yr}$ in other lakes in the northern Great Plains, as well as in sand dune activity, suggest that aridity cycles were the dominant feature of late Holocene climate of the northern Great Plains. (C) 2000 Elsevier Science Ltd and INQUA. All rights reserved.
\end{abstract}

\section{Introduction}

Pickerel Lake, Day County, South Dakota, occupies one of numerous depressions in calcareous glacial till deposited by the Des Moines lobe, a long tongue of the Laurentide ice sheet that extended down the Red River Valley, constrained on its west side by the Coteau du Missouri, and on the east side by the Alexandria moraine complex in Minnesota (Wright, 1993). The lake is just south of the plain of glacial Lake Agassiz, and the climate

\footnotetext{
* Corresponding author.

E-mail address: dean@usgs.gov (W.E. Dean).
}

of the region may have been influenced by the presence of Lake Agassiz during deglaciation and the early Holocene. The high carbonate content of the drift is due to rock flour from Cretaceous carbonate rocks. Fig. 1A shows that, in general, lakes in the eastern Dakotas have higher salinities (as indicated by total dissolved cations) than lakes in adjacent Minnesota. However, the map in Fig. 1A has been highly smoothed during both the gridding and contouring steps, otherwise it would display numerous bulls-eye patterns. Lakes on the Coteau have a wide range of salinities. Lakes with highly saline waters receive discharge from regional flow systems, and nearby lakes with lower salinity waters receive discharge from local flow systems (Winter, 1999). Pickerel Lake is a 

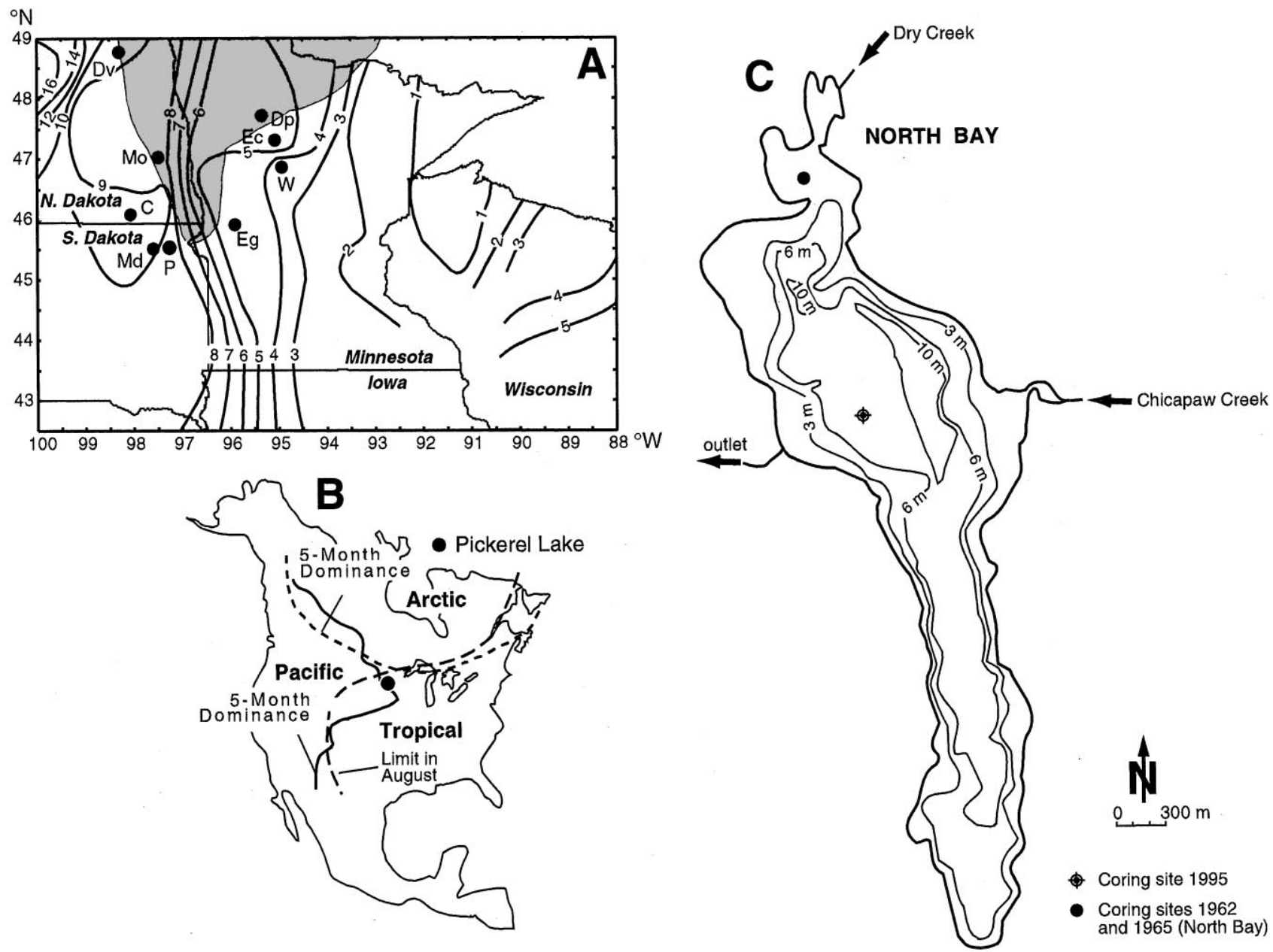

Fig. 1. Maps of (A) contours of total cations in milliequivalents per liter (epm) in lakes in the north-central United States (data of Gorham et al., 1982); shaded area is underlain by sediments deposited in glacial Lake Agassiz; (B) major air masses that affect the climate of North America (modified from Bryson and Hare, 1974); and (C) bathymetry of Pickerel Lake and core sites discussed in this paper. Locations of Pickerel Lake and other lakes discussed in this paper shown on map (A) include: C, Coldwater Lake; Dp, Deep Lake; Dv, Devils Lake; Ec, Elk Lake, Clearwater County; Eg, Elk Lake, Grant County; Md, Medicine Lake; Mo, Moon Lake; P, Pickerel Lake; W, Williams Lake.

relatively dilute magnesium-calcium-bicarbonate lake with total cations of 5.4 milliequivalents per liter (equivalents per million, epm). Therefore, it is probably recharged from a local flow system. Nearby lakes in Day County, South Dakota (and the total cation concentrations of their contained waters) include Waubay Lake (115 epm), Bitter Lake (160 epm), and Hazelden Lake (264 epm) (Gorham et al., 1982). These lakes contain sodium-magnesium-sulfate waters derived from the deep, regional flow system that interacts with the underlying Pierre Shale.

Today, the region of western Minnesota and the eastern Dakotas occurs at a "climatic triple junction" where three regional air masses join to form sharp climatic gradients (Fig. 1B). A warm, moist, tropical Gulf of Mexico air mass dominates in the northern Great Plains during the summer months, whereas the winter months experience competition between a cold, dry Arctic air mass and a dry Pacific air mass. Periods of drought in the Great Plains occur when the dry Pacific air mass dominates over the other two air masses as a result of stronger westerly zonal winds (Bryson, 1966; Muhs, 1985). Computer model simulations (Kutzbach, 1987) suggest that by $12,000 \mathrm{cal}$. yr BP the northeasterly winds generated by the high-pressure cell over the Laurentide ice sheet were replaced by westerly winds.

During summer, circulation around low-pressure systems moving from west to east across continental United States causes substantial northward flow of moist air from the Gulf of Mexico into the north-central states. The contrast between the warm land in southwestern United States and a cooler Pacific Ocean during the summer months (the southwest monsoon effect), and circulation around the west side of the Bermuda highpressure system in the western North Atlantic enhances this northward flow of Gulf moisture. Interaction 
between Gulf air and Arctic air flowing southward produces thunderstorms that provide the principal source of moisture for the north-central United States in the spring and summer. In winter, when circulation is more zonal, the main storm track is oriented from southwest to northeast, and cyclones pull in warm, moist Gulf air that causes heavy snowfalls in the Midwest (Rodinov, 1994). Thus, most of the annual precipitation in the northcentral United States is derived from the Gulf of Mexico (Rozanski et al., 1993; Smith and Hollander, 1999), and precipitation has a steep east-west gradient, decreasing to the west.

This steep east-west climatic gradient across the north-central states is manifested in the chemistry of lake waters, and the total ionic concentration of these waters increases five orders of magnitude from northeastern Minnesota and northwestern Wisconsin to the eastern Dakotas (in terms of total dissolved solids and specific conductivity; 10 -fold in terms of epm total cations, Fig. 1A). Lakes throughout most of Minnesota are dominated by calcium and bicarbonate (Gorham et al., 1982, 1983), but the prairie lakes in western Minnesota and the Dakotas generally are dominated by sodium, magnesium, and sulfate. The change in water chemistry is the result of a combination of high net evaporation from the prairie lakes, loss of calcium and bicarbonate by precipitation of $\mathrm{CaCO}_{3}$ in the lakes, and gain of sodium, magnesium, and sulfate from Cretaceous shales and associate rocks (e.g. limestone, dolomite, and gypsum) that underlie the prairie regions.

All of the prairie lakes precipitate $\mathrm{CaCO}_{3}$ during summer, many precipitate dolomite $\left(\mathrm{CaMg}\left(\mathrm{CO}_{3}\right)_{2}\right.$; Dean and Gorham, 1976), and some precipitate gypsum $\left(\mathrm{CaSO}_{4} \cdot 2 \mathrm{H}_{2} \mathrm{O}\right.$; Radle et al., 1989; Valero-Garces and Kelts, 1995). We selected Pickerel Lake because it is located on the steep climatic gradient described above, and, therefore, may have experienced rapid and extreme climatic transitions during the Holocene that would be recorded in the chemistry and mineralogy of sediments, and in the isotopic composition of $\mathrm{CaCO}_{3}$ in those sediments.

In the 1960s, cores were taken from sites in about $1.6 \mathrm{~m}$ water depth in the sheltered habitat of North Bay of Pickerel Lake (Fig. 1C), and sediments from these cores were analyzed for pollen, seeds, and molluscs (Watts and Bright, 1968), stable isotopes of carbon and oxygen in molluscs (Stuiver, 1970), diatoms (Haworth, 1972), and ostracodes (Smith, 1991). The sediment sequences collected in these two cores were only about $8 \mathrm{~m}$ long and incomplete. In order to carry out a high-resolution study of a complete record from the profundal zone of Pickerel Lake, a $17.7 \mathrm{~m}$ long sediment core was taken in January, 1995, from the ice surface in a water depth of $8.4 \mathrm{~m}$ using a modified Livingstone piston corer with a diameter of $5 \mathrm{~cm}$ (Wright, 1967). Results of carbon- and oxygen-isotope measurements on ostracodes and bulk carbonate (marl) from this core were reported by Schwalb and Dean (1998).

\section{Methods}

Whole-core magnetic susceptibility measurements were made on samples collected at $2 \mathrm{~cm}$ intervals with a Bartington susceptibility bridge in the core laboratory of the Limnological Research Center, University of Minnesota. Magnetic susceptibility in lake sediments largely reflects the presence of detrital magnetite and is thus a proxy for detrital clastic material (e.g. Keen and Shane, 1990; Sprowl and Banerjee, 1993; Dean et al., 1996).

Percentages of organic matter and total carbonate, calculated as $\mathrm{CaCO}_{3}$, were determined by loss on ignition (LOI) at 550 and $1000^{\circ} \mathrm{C}$, respectively (Dean, 1974), at the Limnological Research Center on samples collected every $10 \mathrm{~cm}$. The amount of inorganic, non-carbonate material was calculated as the difference between $100 \%$ and the sum of the percentages of organic matter and total carbonate. This value is often referred to as the "detrital-clastic" fraction, although in the sediments of many lakes this fraction also includes siliceous remains of diatoms. Data on LOI of sediments from Minnesota lakes presented by Dean (1974) indicated that LOI at $550^{\circ} \mathrm{C}$ is approximately twice the organic carbon (OC) content. Numerous subsequent analyses have confirmed this 2-to-1 relation for organic matter in most lake sediments, but in order to test this organic relation and the LOI total carbonate calculation for the sediments of Pickerel Lake, abundances of total carbon (TC) and inorganic (carbonate) carbon (IC) were determined by coulometry (Engleman et al., 1985) at the US Geological Survey, Denver, on samples of bulk sediment collected every $20 \mathrm{~cm}$. Values of $\mathrm{OC}$ were determined by difference between TC and IC. Percentage $\mathrm{CaCO}_{3}$ is calculated by dividing percent carbonate carbon by 0.12 , the fraction of carbon in $\mathrm{CaCO}_{3}$. This conversion probably overestimates total carbonate content slightly because most samples contain minor amounts of dolomite that contains 13 wt $\%$ carbon.

Semi-quantitative estimates of mineral contents of powdered bulk samples were determined by standard X-ray diffraction techniques (e.g. Moore and Reynolds, 1989) at the US Geological Survey, Denver. An aliquot of the powdered sample was packed into an aluminum holder and scanned from $15^{\circ}$ to $50^{\circ} 2 \Theta$ at $2^{\circ} 2 \Theta / \mathrm{min}$ using Ni-filtered, $\mathrm{Cu} \mathrm{K}_{\alpha}$ radiation at $45 \mathrm{kV}, 30 \mathrm{~mA}$.

Stable-isotope measurements of bulk carbonate (marl) were determined at the US Geological Survey, Denver, on splits of the samples used for total and inorganic carbon analyses. $\mathrm{CO}_{2}$ was liberated from each sample using a Finnigan Kiel automated carbonate extraction device and analyzed in line with an isotope-ratio mass spectrometer. In the Kiel device, four drops of $100 \%$ 
phosphoric acid were dripped on each sample in individual reaction vessels and allowed to react at $75 \pm 1{ }^{\circ} \mathrm{C}$ to completion in $10 \mathrm{~min}$. Evolved gases were cryogenically purified to remove water and non-condensible gases in the Kiel device. Purified $\mathrm{CO}_{2}$ from the samples was introduced into the mass spectrometer through a capillary and measured against a reference standard of known isotopic composition. Samples are reported in the usual per mil $(\%) \delta$-notation relative to the Vienna Pee Dee Belemnite (VPDB) marine-carbonate standard for carbon and oxygen:

$\delta \%=\left[\left(R_{\text {sample }} / R_{\mathrm{VPDB}}\right)-1\right] 10^{3}$,

where $R$ is the ratio ${ }^{13} \mathrm{C}:{ }^{12} \mathrm{C}$ or ${ }^{18} \mathrm{O}:{ }^{16} \mathrm{O}$.

Stable-carbon isotope ratios in organic matter were determined using standard techniques (Dean et al., 1986). Acidified samples were combusted at $1000^{\circ} \mathrm{C}$ under oxygen pressure in an induction furnace. The resulting $\mathrm{CO}_{2}$ was dehydrated and purified in a high-vacuum, gastransfer system, and isotope ratios were determined using an isotope-ratio mass spectrometer. Results are reported in the standard per mil $(\%) \delta$-notation relative to the Vienna Pee Dee Belemnite (VPDB) marine-carbonate standard:

$\delta^{13} \mathrm{C} \%=\left[\left(R_{\text {sample }} / R_{\text {standard }}\right)-1\right] 10^{3}$,

where $R$ is the ratio ${ }^{13} \mathrm{C}:{ }^{12} \mathrm{C}$.

\section{Results}

\subsection{Chronology}

The chronology used for this study is based on nine accelerator-mass spectrometer (AMS) ${ }^{14} \mathrm{C}$ ages on fragments of wood, needles, and charcoal (Table 1; Figs. 2 and 3). Both the uncalibrated ${ }^{14} \mathrm{C}$ ages (yr BP) and calibrated ages (calendar yr BP) to account for variations in ${ }^{14} \mathrm{C}$ production in the atmosphere are given in Table 1. Radiocarbon dates younger than $8200 \mathrm{yr}$ BP were calib-

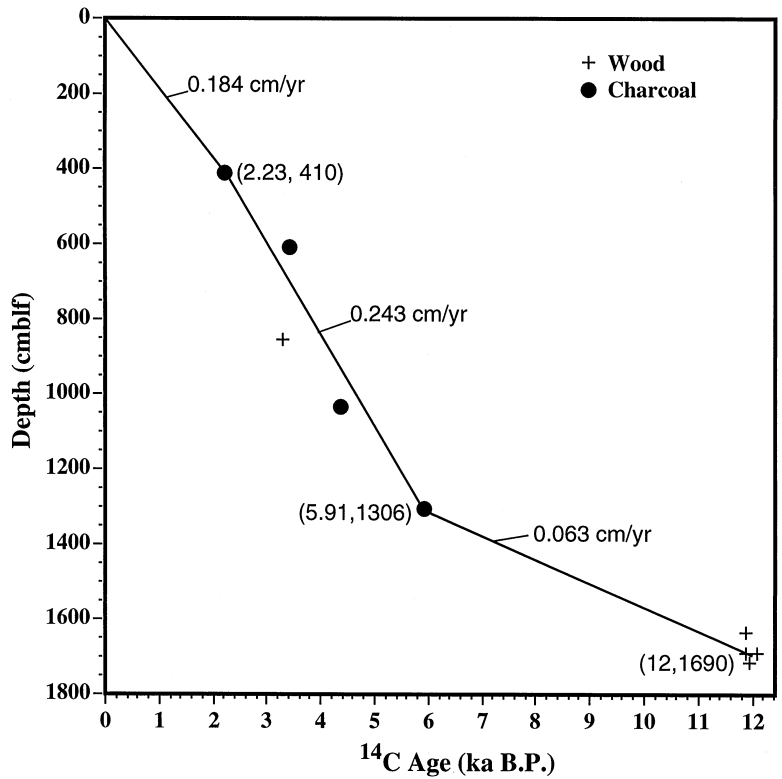

Fig. 2. Plot of ${ }^{14} \mathrm{C}$ age (in thousands of years before 1950, ka BP) versus depth in core (in centimeters below lake floor, cmblf) of radiocarbon dates of samples listed in Table 1. Solid lines represent the age model used to assign ${ }^{14} \mathrm{C}$ ages to depths in core. Sedimentation rates for each of the three segments of the age model are given in centimeters per year $(\mathrm{cm} / \mathrm{yr})$.

rated using the CALIB 3.0 program of Stuiver and Reimer (1993). Radiocarbon dates older than 8200 yr BP were calibrated using the equation of Stuiver et al. (1986): $\mathrm{Cal}=1.05\left({ }^{14} \mathrm{C}\right)+470$, where $\mathrm{Cal}$ is the calibrated age and ${ }^{14} \mathrm{C}$ is the measured radiocarbon age. We used the uncalibrated ages in most of the discussion below mainly to compare the dates at this site with the uncalibrated ages for other published sites and events; when we use calibrated ages, these will be designated "cal. yr BP" or "cal. ka BP". The chronological model we used for the core (Fig. 2) assumes an age of $12 \mathrm{ka} \mathrm{BP}$ at $1690 \mathrm{~cm}$ below lake floor (cmblf; the average age and depth of the four basal radiocarbon ages listed in Table 1); $5.91 \mathrm{ka}$ at

Table 1

Accelerator-mass spectrometer (AMS) ${ }^{14} \mathrm{C}$ ages of plant materials from the deep-basin core from Pickerel Lake (depths in core are in centimeters below lake floor (cmblf))

\begin{tabular}{llllll}
\hline $\begin{array}{l}\text { Sample depth } \\
\text { (cmblf) }\end{array}$ & $\begin{array}{l}\text { Plot depth } \\
\text { (cmblf) }\end{array}$ & Material & $\begin{array}{l}\text { AMS }{ }^{14} \text { C age } \\
(\mathrm{yr} B P)\end{array}$ & $\begin{array}{l}\text { Error } \\
(\mathrm{yr})\end{array}$ \\
\hline $409-411$ & 410 & Charcoal & 2230 & 40 & \multicolumn{1}{c}{$\begin{array}{l}\text { Calibrated age } \\
(\mathrm{cal} . \mathrm{yr} \text { BP })\end{array}$} \\
$600-612$ & 611 & Charcoal & 3430 & 50 & 3790 \\
859 & 859 & Wood & 3290 & 60 & 3490 \\
$1032-1040$ & 1036 & Charcoal & 4390 & 40 & 5080 \\
$1302-1310$ & 1306 & Charcoal & 5910 & 30 & 6680 \\
1636 & 1636 & Wood & 11,880 & 60 & 12,940 \\
$1687-1694$ & 1690 & Spruce needles & 12,070 & 40 & 13,140 \\
$1684-1694$ & 1689 & Spruce wood & 11,879 & 50 & 12,940 \\
$1714-1717$ & 1716 & Spruce wood & 11,960 & 40 & 10,030 \\
\hline
\end{tabular}




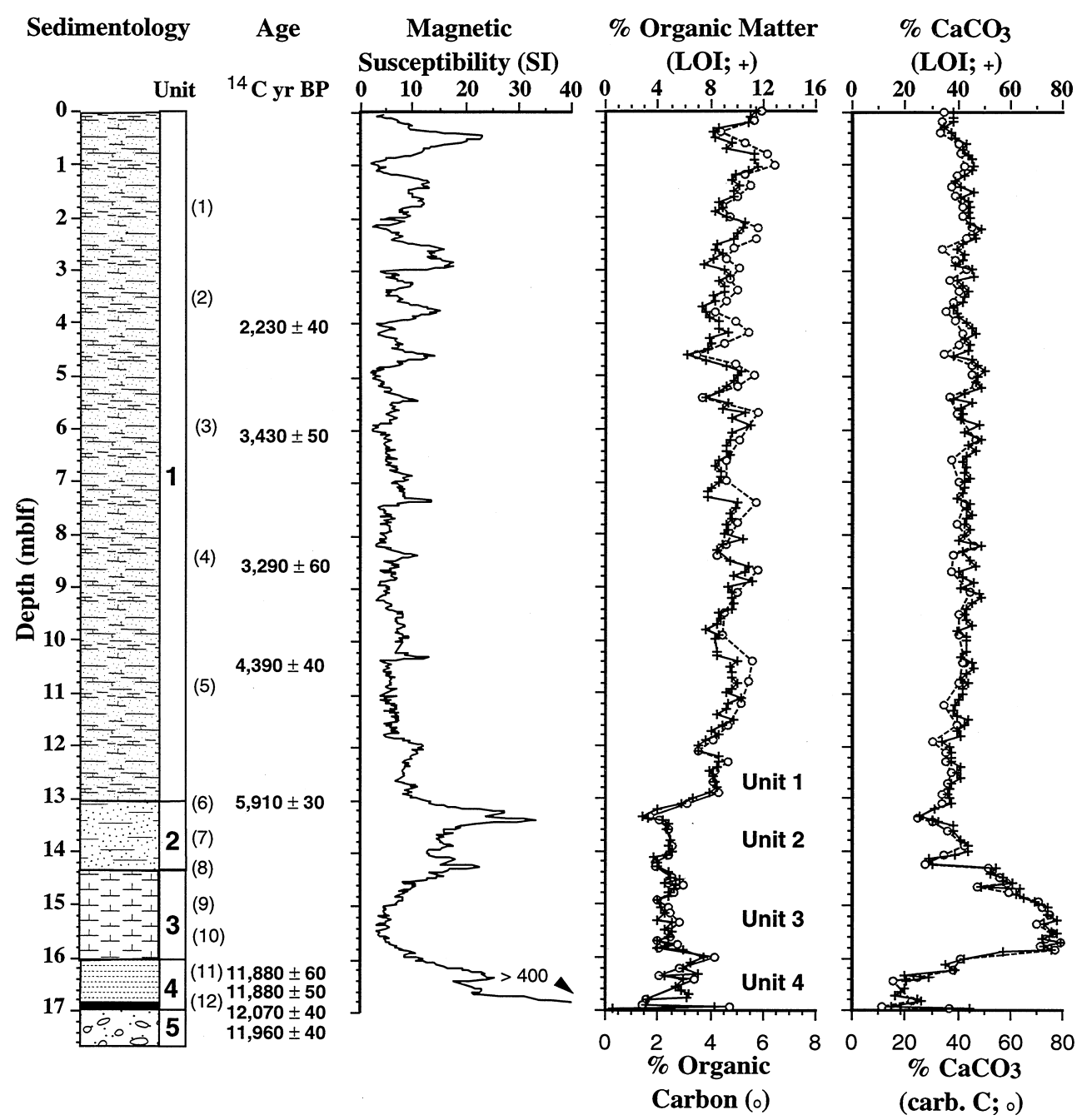

Fig. 3. Lithologic units, ${ }^{14} \mathrm{C}$ dates from Table 1, magnetic susceptibility, and percentages of organic carbon, organic matter, and total carbonate (as $\mathrm{CaCO}_{3}$ ) versus depth in the deep-basin core (in meters below lake floor, mblf). Numbers in parentheses are ages in thousands of years estimated from the age model shown in Fig. 2. Unit 1: marl; unit 2: calcareous sandy silt; unit 3: banded marl; unit 4: clayey silt with laminated sections; unit 5: sand and gravel. LOI = loss on ignition.

1306 cmblf (Table 1); $2.23 \mathrm{ka} \mathrm{BP}$ at $410 \mathrm{cmblf}$ (Table 1); and $0 \mathrm{ka}$ BP at $0 \mathrm{cmblf}$. Assuming a uniform sedimentation rate between these data, the sedimentation rate between the top of the core and $410 \mathrm{cmblf}$ is $0.184 \mathrm{~cm} / \mathrm{yr}$; that between 410 and 1306 is $0.243 \mathrm{~cm} / \mathrm{yr}$; and that between 1306 and $1200 \mathrm{cmblf}$ is $0.063 \mathrm{~cm} / \mathrm{yr}$ (Fig. 2). Using these sedimentation rates, we estimated ages of sediment in the core at $1 \mathrm{kyr}$ intervals (numbers in parentheses in Fig. 3).

\subsection{Lithology and sediment composition}

Most of the sediment in the upper $13 \mathrm{~m}$ of the core (lithologic unit 1, estimated to have accumulated over the last $6 \mathrm{kyr}$ ) consists of massive, olive gray, calcareous mud (marl) with varying amounts of sand and ostracode valves (Fig. 3). The average OC content of this section is
$5 \%(10 \%$ organic matter by LOI $)$ and the average total carbonate content is $40 \%$ with very little variation (Fig. 3). X-ray diffraction analyses of samples of this marl (0 and $680 \mathrm{~cm}$, Fig. 4) show that it is composed mainly of calcite and quartz with minor amounts of dolomite and feldspar. Although the magnetic susceptibility of this sediment is generally low ( $<10$ SI units), the upper six meters of the section is marked by striking $1 \mathrm{~m}$ cycles in susceptibility (Fig. 3). These will be discussed in more detail below.

The total carbonate percentages plotted in Fig. 3 were calculated from measured values of IC by assuming that all of the IC is in calcite. Total carbonate also was calculated by assuming that the weight loss on ignition between 550 and $1000^{\circ} \mathrm{C}$ is from loss of $\mathrm{CO}_{2}$ from calcite (Dean, 1974). Note from Fig. 3 that the amounts of total carbonate (calculated as $\mathrm{CaCO}_{3}$ ) by both methods agree 

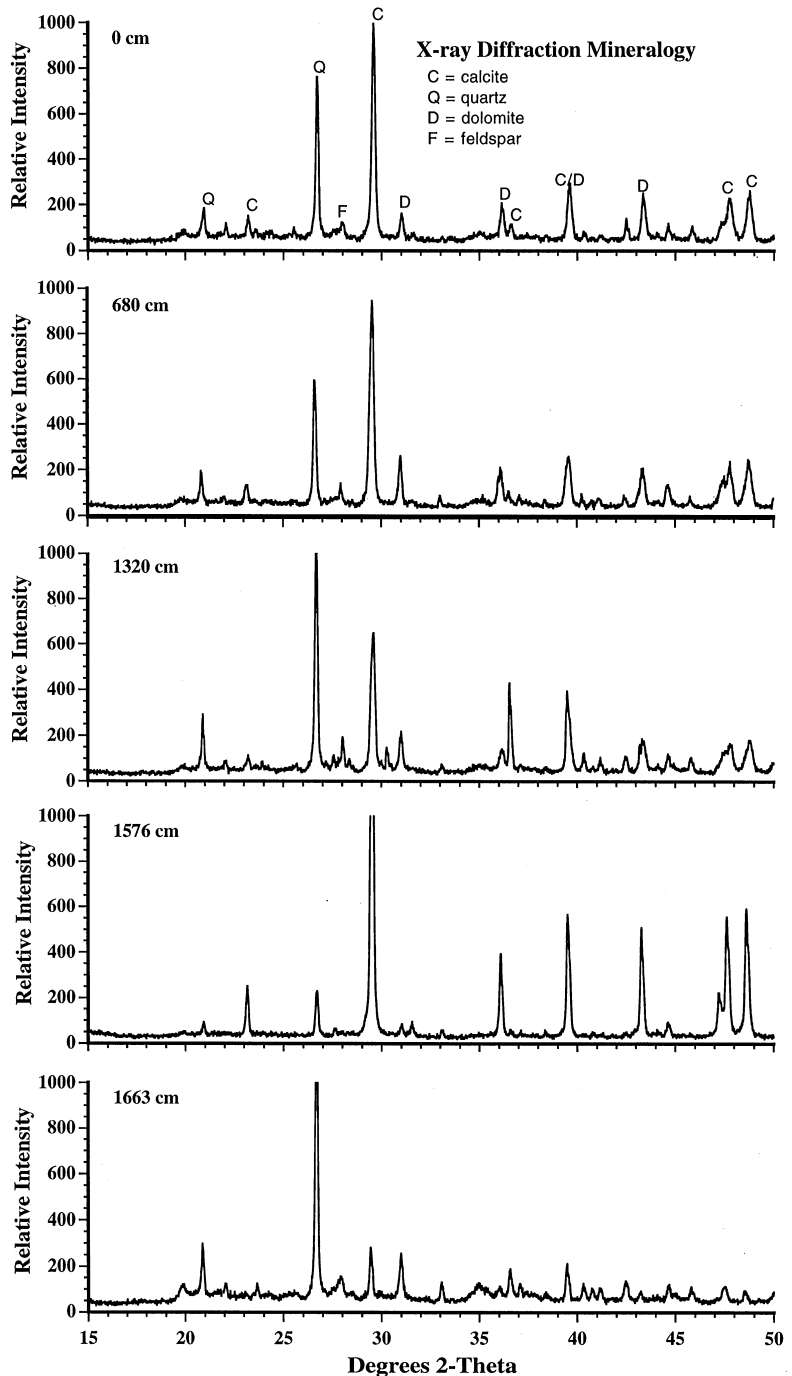

Fig. 4. X-ray diffraction patterns showing the positions (in degrees two theta) and relative intensities (in counts per second) of the major minerals in sediments of Pickerel Lake from selected depths (in centimeters, $\mathrm{cm}$ ) in the deep-basin core.

very well. Note also that there is good agreement between organic matter determined by LOI and OC calculated as the difference between TC and IC, and that the organic matter content is twice the OC content. As mentioned above, assuming that the carbonate is all calcite overestimates total carbonate content slightly if dolomite is present, but, in general, dolomite is a very minor mineral component compared with calcite (Fig. 4).

Lithologic unit 2 (13-14.5 m; Fig. 3) contains a higher detrital-clastic fraction that is manifested by higher magnetic susceptibility, much more sand (Schwalb and Dean, 1998), lower OC content (Fig. 3), and higher quartz and feldspar content $(1320 \mathrm{~cm}$, Fig. 4). The lower organic content continues into the underlying lithologic unit 3 that consists of faintly banded marl (14.5-16.1 m). The faint bands are the manifestation of alternating $2-3 \mathrm{~cm}$ thick silty clay layers with carbonate-rich clay layers. The entire unit has low magnetic susceptibility and contains only about $2 \%$ OC. The total carbonate content of unit 3 is much higher than that in units 1 and 2, with a maximum of about $80 \%$ (Fig. 3), and that carbonate is almost entirely calcite $(1576 \mathrm{~cm}$, Fig. 4). The base of unit 3 is marked by a sharp decrease in carbonate and an increase in magnetic susceptibility (Fig. 3) and detrital-clastic material (Schwalb and Dean, 1998).

Lithologic unit $4(16.1-17 \mathrm{~m})$ is composed mostly of gray, homogeneous clayey silt to silty clay with a few laminated sections. It is composed mostly of quartz with minor amounts of calcite, dolomite, and feldspar (1663 $\mathrm{cm}$, Fig. 4). The OC and carbonate contents are both low, and the high detrital-clastic content is reflected in the high magnetic susceptibility (Fig. 3). Much if not most of the calcite and dolomite in this unit may be detrital, derived from unweathered calcareous glacial drift. The base of this unit is a $7 \mathrm{~cm}$ thick dark gray trash layer of silt and sand with organic debris (twigs, cones, needles, and other remains of trees). The bottom $0.7 \mathrm{~m}$ of the core (lithologic unit 5) consists of sand and gravel that is probably glacial drift; it is characterized by the highest magnetic susceptibility values in the core (up to 400 SI units; Fig. 3). Radiocarbon analyses of spruce wood and needles from unit 4 and the top of unit 5 (Table 1; Figs. 2 and 3) all give ages of about $12 \mathrm{ka}$.

\subsection{Isotopes}

Despite the fact that Pickerel Lake is located on a steep climatic gradient, as indicated by historic climate data, vegetation change, and water chemistry (Fig. 1A), the marls of lithologic unit 1 show surprisingly little variation in either $\delta^{18} \mathrm{O}$ or $\delta^{13} \mathrm{C}$ (Figs. 5A and $\mathrm{B}$ ). There is also little variation in $\delta^{13} \mathrm{C}$ of $\mathrm{OC}$ throughout lithologic unit 1 . Below $13 \mathrm{~m}$, however, there are significant variations in $\delta^{13} \mathrm{O}$ of $\mathrm{OC}$, and in $\delta^{18} \mathrm{O}$ and $\delta^{13} \mathrm{C}$ of marl (Figs. 5A and B). The positive spike in both $\delta^{18} \mathrm{O}$ and $\delta^{13} \mathrm{C}$ in marl at $6.5 \mathrm{ka}$ probably is due to increased influx of detrital carbonate from calcareous glacial drift, further supported by the high values of magnetic susceptibility. The most striking feature of the carbon isotopic composition of OC and marl in lithologic units 2 and 3 is the marked monotonic increase upward in $\delta^{13} \mathrm{C}$ by about $7 \%$ in OC and $6 \%$ in marl (Fig. 5B). Ignoring the positive spike at $6.5 \mathrm{ka}$, there is a monotonic increase of about $2 \%$ in $\delta^{18} \mathrm{O}$ in marl between 10.4 and $6 \mathrm{ka}$ (Fig. 5A).

\section{Discussion}

\subsection{Lake history}

Because the four basal radiocarbon ages all have almost identical values (ca. $12 \mathrm{ka}$; Table 1), the trash layer 


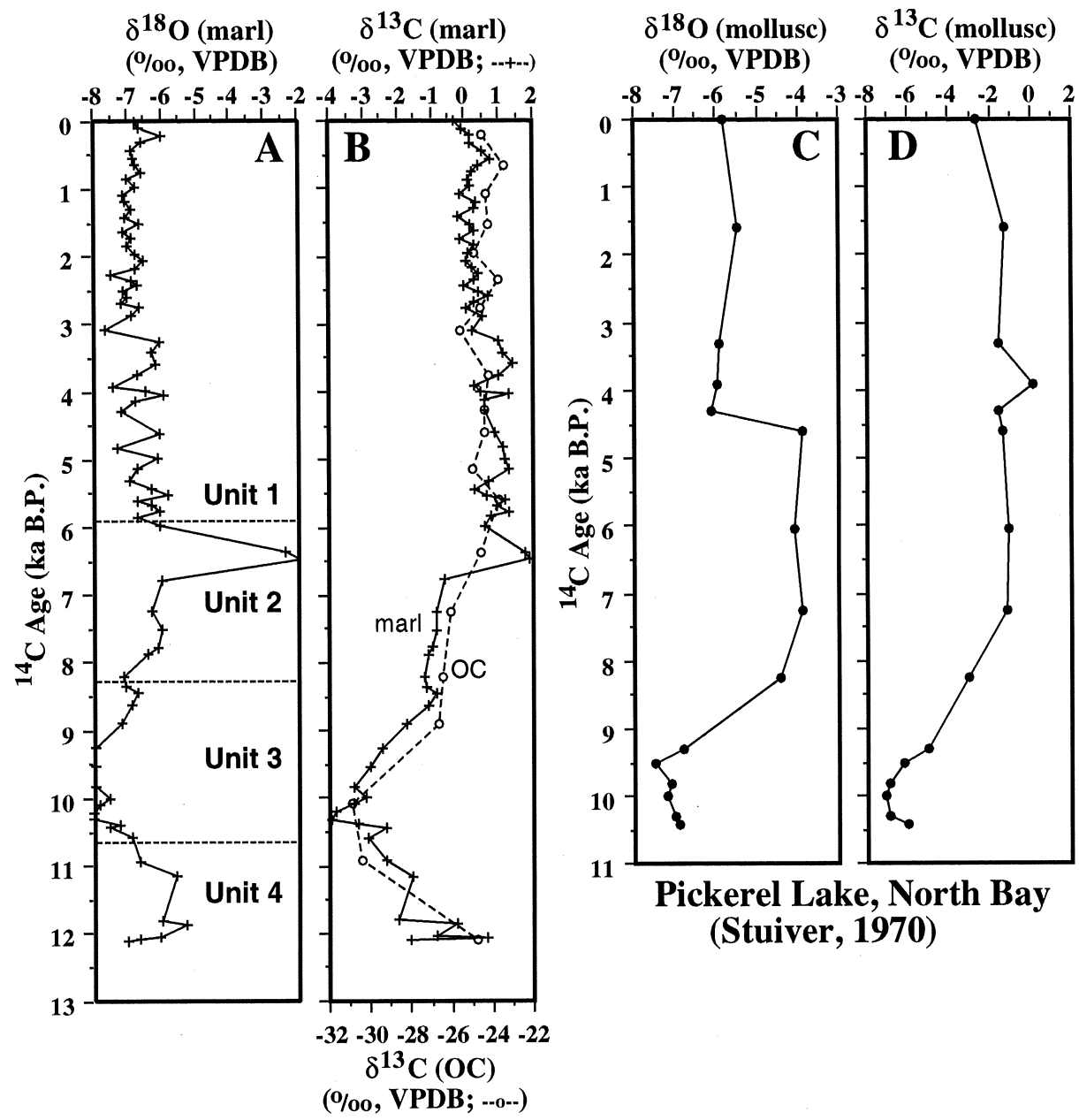

Fig. 5. Isotopic composition of oxygen in bulk carbonate (marl) (A) and carbon in bulk carbonate (marl) and organic carbon (OC) (B) versus ${ }^{14} \mathrm{C}$ age (in thousands of years before 1950, ka BP); and of oxygen (C) and carbon (D) in mollusc shells in a core from North Bay of Pickerel Lake versus ${ }^{14} \mathrm{C}$ age (in thousands of years before 1950, ka BP; modified from Stuiver, 1970). Units correspond to lithologic units in Fig. 3. The ${ }^{14} \mathrm{C}$ ages are based on the age model in Fig. 2.

at the base of unit 4 may not have been deposited in an open-water lake, but rather may represent a supraglacial forest floor, either developed in place or transported only a short distance, as has been described from the bases of cores from many lakes in Minnesota (e.g. Wright, 1993). Ages of basal woody trash layers in lakes of the Itasca region of northwestern Minnesota are about $11 \mathrm{ka}$ (Wright, 1992) suggesting that a change from tundra conditions to spruce forest occurred about $1000 \mathrm{yr}$ earlier at Pickerel Lake than in the Itasca region, which is $290 \mathrm{~km}$ to the northeast. Unit 4 contains an average of about $75 \%$ detrital clastic material (Schwalb and Dean, 1998), which accounts for the high magnetic susceptibility (Fig. 3). The carbonate content of unit 4 is generally $<20 \%$, and that of OC $<2 \%$. The carbonate material, like everything else in unit 4, is probably also detrital, derived from Cretaceous bedrock, further indicated by the relatively high values of $\delta^{18} \mathrm{O}$ and $\delta^{13} \mathrm{C}$, particularly at the base of the unit (Figs. 5A and $\mathrm{B}$ ). Carbonate rocks deposited in the Western Interior Seaway tend to be depleted in ${ }^{18} \mathrm{O}$ (negative values of $\delta^{18} \mathrm{O}$ ) relative to Cretaceous open-marine carbonates (values of $\delta^{18} \mathrm{O}$ of about zero) because of the influx of meteoric water from the Sevier orogenic belt along the western margin of the Seaway (Ludvigson et al., 1994; Dean and Arthur, 1998).

Unit 3 represents the first deposition of fine-grained sediment in a stable, open-water lake environment. Between the top of unit 4 and the base of unit 3, the rapid decrease in detrital-clastic material (as indicated by lower magnetic susceptibility; Fig. 3) and rapid increase in the amount of carbonate (Fig. 3), mostly calcite, suggest either that the influx of detrital clastic material was suddenly reduced, or that the lake became saturated with respect to calcite and started precipitating massive amounts of calcite that diluted the detrital clastic fraction. We prefer the latter explanation because pulses of carbonate in late deglacial to early Holocene lake sediments are common in lakes in calcareous drift (e.g. Dean 


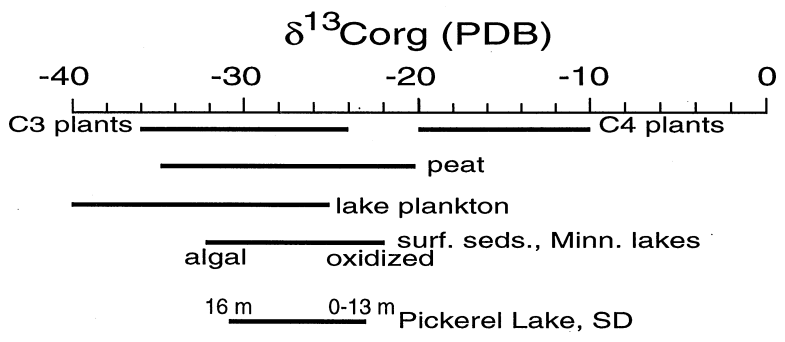

Fig. 6. Ranges of values of $\delta^{13} \mathrm{C}$ of organic carbon in samples of sediment from the deep-basin core of Pickerel Lake, surface sediments of Minnesota lakes (ranging from algal-rich to oxidized), lake plankton, peat, $\mathrm{C}_{4}$ plants, and $\mathrm{C}_{3}$ plants. Data for $\delta^{13} \mathrm{C}$ in lake Minnesota lake sediments are from Dean and Stuiver (1993). Data for $\delta^{13} \mathrm{C}$ in peat, lake plankton, $C_{4}$ plants, and $C_{3}$ plants were compiled from Bender (1971), Deines (1980), and Cerling and Quade (1993).

and Megard, 1993) due to rapid initial leaching of carbonate from fresh calcareous glacial drift followed by a gradual decline as carbonate was progressively depleted from the drift. The asymmetrical shape of the carbonate curve for lithologic unit 3 (Fig. 3) suggests that such a pulse occurred in Pickerel Lake. Diatoms in sediments deposited in North Bay of Pickerel Lake were predominantly acidophilous below an interval dated at $9400{ }^{14} \mathrm{C}$ yr BP, and predominantly alkaliphilous above that horizon (Haworth, 1972).

It is tempting to interpret the marked decreases in values of $\delta^{13} \mathrm{C}$ in both OC and marl through unit 4 and into the base of unit 3 (Fig. 5B) as due to a change in source of organic matter from tundra with perhaps a mixture of $\mathrm{C}_{3}$ and $\mathrm{C}_{4}$ plants, to spruce forest with predominantly $\mathrm{C}_{3}$ plants. $\mathrm{C}_{3}$ and $\mathrm{C}_{4}$ plants have very different $\delta^{13} \mathrm{C}$ values (Fig. 6), averaging about -27 and $-12 \%$, respectively (Cerling and Quade, 1993). Lacustrine algal organic matter tends to have $\delta^{13} \mathrm{C}$ values ranging from the high negative 20 s to the low negative 30s (Dean and Stuiver, 1993). However, numerous carbon-isotope analyses of organic matter in soils from arctic tundra in the foothills and coastal plain of Alaska by Muhs et al. (2000) have a narrow range of $\delta^{13} \mathrm{C}$ values $\left(-26.0\right.$ to $-26.9 \%$ ), within the range of $\delta^{13} \mathrm{C}$ values of organic matter in upland spruce-birch forest $(-25.4$ to $-27.7 \%$ ), suggesting that tundra, at least in Alaska, consists mainly of $\mathrm{C}_{3}$ plants. Pollen from sediments collected in a core from shallow North Bay of Pickerel Lake (Fig. 1C) indicates that a boreal forest dominated by spruce (Picea) surrounded the lake until about 10,670 ${ }^{14} \mathrm{C}$ yr BP. The basal four radiocarbon dates are all from spruce wood or needles (Table 1). Therefore, we have no explanation for the distinctly higher values of $\delta^{13} \mathrm{C}$ at the base of unit 4 , and the marked decrease in $\delta^{13} \mathrm{C}$ throughout unit 4 and into unit 3 .

The maximum extent of Lake Agassiz occurred between about 11,600 and $9500{ }^{14} \mathrm{C}$ yr BP (Teller, 1985, 1987), that is during deposition of the top of unit 4 and the bottom of unit 3. The close proximity of Lake Agassiz to Pickerel Lake suggests that it may have had some effect on the climate in the Pickerel Lake area. It is tempting, therefore, to suspect that the shift to ${ }^{18} \mathrm{O}$ depleted carbonate in marl deposited in unit 3 was related to the presence of Lake Agassiz. Lower $\delta^{18} \mathrm{O}$ values of precipitation might be expected due to openwater evaporation from the lake as seen on the lee side of the Great Lakes area today (Gat et al., 1994). Although this lake effect seems reasonable and may indeed have influenced Pickerel Lake, the coincidence of the lowest values of $\delta^{18} \mathrm{O}$ with highest carbonate (mostly calcite) abundance in the history of the lake suggests that both were due to massive precipitation of calcite from warmer, late summer, low salinity, open-lake waters.

Increases in values of $\delta^{18} \mathrm{O}$ and $\delta^{13} \mathrm{C}$ in marl beginning in unit 3 and continuing throughout unit 2 (Figs. 5A and $\mathrm{B})$, suggest that the flow-through time of water in the lake increased, i.e. residence time of water in the lake increased. A positive covariance between values of $\delta^{18} \mathrm{O}$ and $\delta^{13} \mathrm{C}$ in marl in a hydrologically open lake in Michigan was explained by Drummond et al. (1995) as due to precipitation of carbonate late in the summer when epilimnetic waters are enriched in ${ }^{18} \mathrm{O}$ because of evaporation, and enriched in ${ }^{13} \mathrm{C}$ because of removal of ${ }^{13} \mathrm{C}$ depleted algal biomass (see also McKenzie, 1985). A climatic trend toward longer summers would result in a greater proportion of ${ }^{18} \mathrm{O}$-enriched summer precipitation (Nativ and Riggio, 1990; Rozanski et al., 1993; Simpkins, 1995) and warm-month productivity. A trend toward longer winters would have the opposite effect. Although such an explanation may have contributed to the observed covariance between $\delta^{18} \mathrm{O}$ and $\delta^{13} \mathrm{C}$ in units 3 and 2, there is no corresponding change in OC content (Fig. 3) to suggest an increase in productivity. The OC contents of sediments in units 3 and 2 are low with very little variation, and then increase suddenly near the end of deposition of unit 2 (Fig. 3). Therefore, an increase in water-residence time seems more reasonable, probably accompanied by a higher evaporation rate.

The trends in $\delta^{18} \mathrm{O}$ and $\delta^{13} \mathrm{C}$ of marl (Figs. 5A and B) resemble those in $\delta^{18} \mathrm{O}$ and $\delta^{13} \mathrm{C}$ of molluscs reported by Stuiver (1970) from sediments in North Bay (Figs. 5C and $\mathrm{D})$, in which values of $\delta^{18} \mathrm{O}$ and $\delta^{13} \mathrm{C}$ both increase between 10 and $7 \mathrm{ka}$ (Stuiver, 1970). Values of $\delta^{13} \mathrm{C}$ in North Bay molluscs remain constant through the rest of the Holocene section, but values of $\delta^{18} \mathrm{O}$ decrease abruptly at $4.5 \mathrm{ka}$.

There are several other possible explanations for the positive shift of about $2 \%$ in values of $\delta^{18} \mathrm{O}$ between units 3 and 2 (Fig. 5A) in addition to the increase in residence time discussed above. The change could represent a shift from ${ }^{18} \mathrm{O}$-depleted Arctic or Pacific moisture to ${ }^{18} \mathrm{O}$-enriched moisture from the Gulf of Mexico that is the dominant moisture source in the region today (Nativ and Riggio, 1990; Simpkins, 1995). It is also possible that 
the change represents a shift in dominant precipitation from ${ }^{18} \mathrm{O}$-depleted winter snow to ${ }^{18} \mathrm{O}$-enriched summer rain. Although both are possible, the marked covariance between $\delta^{18} \mathrm{O}$ and $\delta^{13} \mathrm{C}$ in units 3 and 2 suggests that the positive shift is mainly due to hydrology of the lake, with longer flow-through time and greater net evaporation.

A $2 \%$ decrease in $\delta^{18} \mathrm{O}$ in bulk carbonate in varved sediment in a core from Deep Lake in Clearwater county, Minnesota, just north of Elk Lake, at 8900 cal. yr BP $\left(8000{ }^{14} \mathrm{C}\right.$ yr BP) was interpreted by Hu et al. $(1997,1999)$ as due to increased outbreaks of polar air, colder temperatures, and more precipitation falling as snow in response to drainage of Lakes Agassiz and Ojibway northward through Hudson Strait. This event does not appear to be recorded in the bulk sediment or ostracode oxygen-isotope records in the sediments of Pickerel Lake; the trend is going in the opposite direction, and extends over a period of about 2 kyr. The Deep Lake oxygen-isotope event predates the prominent " 8.2 cal. ka cold event" (7.4 ${ }^{14} \mathrm{C} \mathrm{ka}$ ) that has been documented in Greenland and elsewhere, and also has been linked to the proposed catastrophic drainage of Lakes Agassiz and Ojibway (see reviews by Alley et al., 1997; Klitgaard-Kristensen et al., 1998; von Grafenstein et al., 1998; Barber et al., 1999). It might be that the Deep Lake cold event is really coincident with the well-documented $8.2 \mathrm{ka}$ cold event. Although the rates of change of proxy variables in the Deep Lake core are varve calibrated, it is a "floating" varve chronology hung on a single "reliable" AMS radiocarbon date. From our own experiences with radiocarbon dates from the Pickerel Lake core alone, we know that some AMS radiocarbon dates are more reliable than others. It is entirely possible that the absolute Deep Lake chronology could be $700 \mathrm{yr}$ too old and that the cold event documented by oxygen isotopes is coincident with the widespread 8.2 cal. ka event.

This "catastrophic" event, and the events leading up to it, may be indirectly responsible for the pulse in detrital clastic material in Pickerel Lake in units 3 and 2 (Fig. 3), peaking between about 7 and $6{ }^{14} \mathrm{C}$ ka ( 8 and 7 cal. ka). There is some question as to whether this increased clastic influx was river-borne or air-borne. By about 9.5 ${ }^{14} \mathrm{C}$ ka, the Laurentide ice sheet had retreated far enough northward that Lake Agassiz was able to drain eastward into Lake Superior, thence through the other Great Lakes into the Gulf of St. Lawrence (Teller, 1985, 1987). At that time, drainage southward from Lake Agassiz, mainly down the present Minnesota River into the Mississippi River, was greatly reduced (Wright et al., 1998). It seems likely, therefore, that other drainages in proximity of the rapidly decreasing Lake Agassiz, such as the streams entering Pickerel Lake, if anything would have decreased. Therefore, the increase in detrital influx in Pickerel Lake most likely is wind-borne (eolian). The rapid retreat of the ice sheet and draining of Lakes Agassiz and Ojibway must have had a profound effect on oceanic and atmospheric circulation. Most studies of the 8.2 cal. ka event have focused on North Atlantic circulation (e.g. Barber et al., 1999), but, as Hu et al. (1999) point out, there must have been significant reorganization of atmospheric circulation patterns. They suggested that one manifestation of this reorganization was strengthening of westerly zonal winds. Increased varve thickness in Deep Lake coincident with the cold event, and continuing for at least $1000 \mathrm{yr}$ thereafter (to the top of the record reported), led $\mathrm{Hu}$ et al. (1999) to conclude that this increased varve thickness reflected increased eolian dust input.

Elk Lake, Clearwater county, northwestern Minnesota, records an eolian signal external to the lake, as well as numerous internal chemical and biological signals resulting from external forcing, at precisely 8200 varve years ago ( $8.2 \mathrm{cal}$. $\mathrm{ka} \mathrm{BP})$. At that time, the lake underwent a dramatic change from a highly stratified, probably meromictic, lake recorded in the sediments by high concentrations of iron, manganese, phosphorus, molybdenum, and sulfur, to a well-mixed lake receiving larger amounts of detrital clastic material as proxied by quartz and numerous lithophile elements such as $\mathrm{Si}, \mathrm{Al}, \mathrm{Mg}$, $\mathrm{Ti}$, $\mathrm{K}$, and many trace elements interpreted as having been transported by eolian dust (Dean, 1993; Bradbury et al., 1993). Other manifestations of increased detrital influx are increased varve thickness and magnetic susceptibility (Bradbury et al., 1993). Prior to $8.2 \mathrm{cal}$. ka, low winds and strong stratification caused diatoms to sink and allowed blooms of cyanobacteria (blue-green algae) (Bradbury and Dieterich-Rurup, 1993), further indicated by high concentrations of prokaryote pigments (Sanger and Hay, 1993). After $8.2 \mathrm{cal}$. ka, increased wind-driven circulation recycled phosphorus, which previously had been sequestered in the sediments, greatly increasing diatom productivity, dominated by the phosphate-dependent diatom Stephanodiscus minutulus (Bradbury and DieterichRurup, 1993). Increased productivity in Elk Lake is further indicated by higher concentrations of chlorophyll and carotenoid pigments in the sediments (Sanger and Hay, 1993). Prairie vegetation, indicated by Quercus, Gramineae, and Artemisia, began to increase at $8.5 \mathrm{cal}$. $\mathrm{ka}$, and was most abundant after $8.0 \mathrm{cal}$. ka (Whitlock et al., 1993). Thus, the regional 8.2 cal. ka "event", supposedly related to the catastrophic final drainage of lakes Agassiz and Ojibway into the Labrador Sea, ushered in the "prairie period" to Minnesota, and increased aridity and eolian activity to the Northern Great Plains in general.

Increased regional aridity and a higher evaporation rate in Pickerel Lake during deposition of unit 2 might also have lowered the lake level leading to erosion of detrital-clastic material from the littoral zone as suggested by the marked increase in magnetic susceptibility in unit 2 (Fig. 3). The unusually high values of $\delta^{13} \mathrm{C}$ and, especially, $\delta^{18} \mathrm{O}$, in marl at the top of unit 2 (Fig. 3), 
coincident with the peak in magnetic susceptibility (Fig. 4), probably are due to detrital carbonates washed into the center of the lake by erosion during lowered lake level. A $50 \mathrm{~cm}$ sand layer was described in a core from North Bay about $1 \mathrm{~m}$ above a horizon dated at 9400 ${ }^{14} \mathrm{C}$ yr BP, and about $1 \mathrm{~m}$ below a horizon dated at 4200 ${ }^{14} \mathrm{C}$ yr BP (Haworth, 1972). Pollen from the sediments in North Bay indicate that during the early Holocene, the lake was surrounded by mixed deciduous woodland, but the abundance of grass pollen suggests that there was still abundant open grassland (Watts and Bright, 1968). By about $8 \mathrm{ka}$ (base of unit 2) pollen from North Bay indicated that the Lake was surrounded by bluestem prairie.

Above we concluded that the covariant increases in values of $\delta^{13} \mathrm{C}$ and $\delta^{18} \mathrm{O}$ in units 3 and 2 were mainly due to increased water-residence time. However, the increase in values of $\delta^{13} \mathrm{C}$ in organic matter exactly parallels an increase in values of $\delta^{13} \mathrm{C}$ in marl (Fig. 5). This suggests that the change from forest to prairie conditions, with a greater proportion of $\mathrm{C}_{4}$ grasses (higher values of $\delta^{13} \mathrm{C}$; Fig. 6), may have had an even greater influence than residence time by providing more ${ }^{13} \mathrm{C}$ to soils and hence to the DIC pool in the lake. Both factors could have produced more ${ }^{13} \mathrm{C}$-enriched carbon values in marl, just as longer residence time and a change in precipitation source could have produced more ${ }^{18} \mathrm{O}$ enrichment.

The transition to a more productive mid-Holocene prairie lake occurred fairly rapidly and is recorded in the top of unit 2 marl by a sharp increase in the concentration of OC to values about twice those in sediments of units 2 and 3 (Fig. 3). This change is recorded in the sediments of North Bay by a marked increase in the abundance of planktonic diatoms, and particularly diatoms indicative of more eutrophic conditions (e.g. Fragilaria crotonensis; Haworth, 1972).

There is abundant paleolimnological evidence for lower levels and higher salinities in lakes of the northern Great Plains during the mid-Holocene. For example, a diatom-inferred transfer function developed by Fritz (Fritz, 1990, 1996; Fritz et al., 1991, 1993) has been applied to cores from several lakes in the northern Great Plains of the United States to document high mid-Holocene salinities, mainly between about 7 and $5 \mathrm{ka}$. Laird et al. (1996a, b, 1998) documented high diatom-inferred salinities in Moon Lake, North Dakota between 7.3 and $2.2 \mathrm{ka}$, with highest salinities occurring between 7.3 and $4.5 \mathrm{ka}$, when laminae of gypsum and aragonite accumulated in the sediments. Laird et al. (1996a) also provide a review of Holocene lake and climatic conditions based on published records from the northern Great Plains. Haskell et al. (1996) used diatom-inferred salinity as well as sodium (Na) concentrations and $\mathrm{Sr} / \mathrm{Ca}, \mathrm{Mg} / \mathrm{Ca}$, and $\mathrm{Ba} / \mathrm{Ca}$ ratios in ostracode shells and bulk carbonate to document Holocene salinity changes in Devils Lake,
North Dakota. They found that highest salinities occurred between 9.5 and $4.5 \mathrm{ka}$, with maximum salinity at $8.0 \mathrm{ka}$. Based on values of $\delta^{18} \mathrm{O}$ and $\mathrm{Sr} / \mathrm{Ca}$ ratios in ostracode shells in sediments from Coldwater Lake, North Dakota, Xia et al. (1997) concluded that the salinity of the lake increased between 10.8 and $8.9 \mathrm{ka}$, and had a maximum salinity between 8.9 and $6.5 \mathrm{ka}$. Across the border in Elk Lake, Grant County, Minnesota (not the Elk Lake in Clearwater County discussed earlier), low, alkaline lake stand beginning about $7.2 \mathrm{ka}$ is indicated by the presence of the saline ostracode Limnocythere staplini, with maximum abundance at about $4.5 \mathrm{ka}$ (Smith, 1991, 1993; Smith et al., 1997). Williams Lake in west-central Minnesota evolved from a hydrologically open lake at $10 \mathrm{ka}$ to a closed lake by about $5 \mathrm{ka}$ (Schwalb et al., 1995). Closer to Pickerel Lake, diatom and sediment evidence suggest that the salinity of Medicine Lake, South Dakota, just west of Pickerel Lake, increased rapidly during the early Holocene, becoming permanently stratified (meromictic) and saline at $9.0 \mathrm{ka}$ when laminated sediments containing gypsum crystals began to accumulate (Radle et al., 1989). Carbon- and oxygenisotope data suggest that Medicine Lake was hypersaline and meromictic during the early to middle Holocene (Valero-Garces and Kelts, 1995). Moon, Devils, Coldwater, and Medicine Lakes in the Dakotas, and Williams Lake in Minnesota, all evolved from hydrologically open conditions to more or less hydrologically closed conditions within a few thousand years during the early Holocene. In contrast, Pickerel Lake probably remained a flow-through lake but with a reduced flow and increased residence time. In addition, Moon, Devils, Coldwater, and Medicine Lakes on the Coteau du Missouri in the Dakotas have salinities that are considerably higher than that of Pickerel Lake indicating that they are fed by the regional groundwater flow system.

Whatever the cause or causes of the isotopic shifts in carbon (organic and carbonate) and oxygen in the sediments of Pickerel Lake between units 3 and 2 were, the hydrology of the lake and the surrounding landscape appear to have reached an equilibrium by about $6 \mathrm{ka}$ (top of unit 2) because the bulk composition of the sediments (indicated by OC, carbonate, and magnetic susceptibility; Fig. 3), the isotopic composition of the organic matter (Fig. 5B), and the isotopic composition of carbonate (Figs. 5A and B) change very little in the upper $13 \mathrm{~m}$ of the core. Values of $\delta^{18} \mathrm{O}$ in the ostracode Candona ohioensis show several pulses of lighter values throughout this interval (unit 1) that were interpreted as representing periods of increased ground-water influx (Schwalb and Dean, 1998), but these events recorded by ostracodes at the sediment-water interface apparently did not affect the isotopic composition of DIC in surface waters during late-summer carbonate precipitation. The abrupt decrease in values of $\delta^{18} \mathrm{O}$ in molluscs from the North Bay core at about $4.5 \mathrm{ka}$ (Fig. 5C) suggests that 
the lake may have become less saline. This same feature does not appear in the $\delta^{18} \mathrm{O}$ record for marl in the deep-basin core (Fig. 5A). The mid-Holocene oxygenisotope plateau in molluscs in the North Bay core (Fig. 5C) suggests that sheltered conditions in the bay resulted in greater evaporation than in the open lake. The stream that enters North Bay (Dry Creek; Fig. 1C) is not fed by upstream lakes, whereas the stream that enters the main lake (Chickapaw Creek; Fig. 1C) is fed by two larger upstream lakes, the Drywood Lakes. It may be that during the mid-Holocene Dry Creek was just that, a dry creek, whereas Chickapaw Creek provided a constant, but reduced, flow. This may explain the relatively constant chemical and isotopic composition of the marl in the open-lake core.

\subsection{Aridity cycles in last $2000 \mathrm{yr}$}

As we pointed out above, magnetic susceptibility exhibits distinct $1 \mathrm{~m}$ cycles in the top $6 \mathrm{~m}$ of section (Fig. 4). We suggested earlier that the large variations in magnetic susceptibility at the base of the core were due to variations in detrital-clastic material, and we extend that interpretation to the $1 \mathrm{~m}$ cycles at the top of the core. The cycles in susceptibility show an excellent positive correlation with cycles in mass accumulation rate (MAR) of inorganic, non-carbonate material determined by LOI (Schwalb and Dean, 1998) (Fig. 7). This fraction is often taken as the detrital-clastic fraction, but in the case of Pickerel Lake (and probably many other lakes) this fraction also includes biogenic silica debris from diatoms. The cycles in magnetic susceptibility correlate negatively with cycles in $\mathrm{OC}$ and $\mathrm{CaCO}_{3}$ content, which might be taken as an indication that productivity is inversely related to clastic influx. This negative correlation with percent $\mathrm{OC}$ and $\mathrm{CaCO}_{3}$ probably represents dilution of these two fractions with detrital-clastic material. The negative correlation disappears when $\mathrm{OC}$ and $\mathrm{CaCO}_{3}$ contents are expressed as MARs rather than relative concentrations (illustrated for OC-MAR in Fig. 7). However, a hint of an inverse relation between organic productivity and detrital influx is suggested by a negative correlation between magnetic susceptibility and values of $\delta^{13} \mathrm{C}$ of marl (Fig. 7). One possible productivity association might be as follows: if the clastic material is brought in mainly by wind rather than the two intermittent streams, then decreased clastic influx would mean less windy conditions, and, if this occurred during the summer, it might permit more intense blooms of cyanobacteria with a greater flux of ${ }^{12} \mathrm{C}$-enriched $\mathrm{OC}$ to the sediments and enrichment of the DIC pool in ${ }^{13} \mathrm{C}$ (heavier carbon in precipitated marl). A similar lowwind-productivity connection was proposed by Dean et al. (1994) for Elk Lake, Clearwater County, for the period from 1300 to $1550 \mathrm{cal}$. yr BP. Geochemical and diatom evidence from sediments of Elk Lake deposited

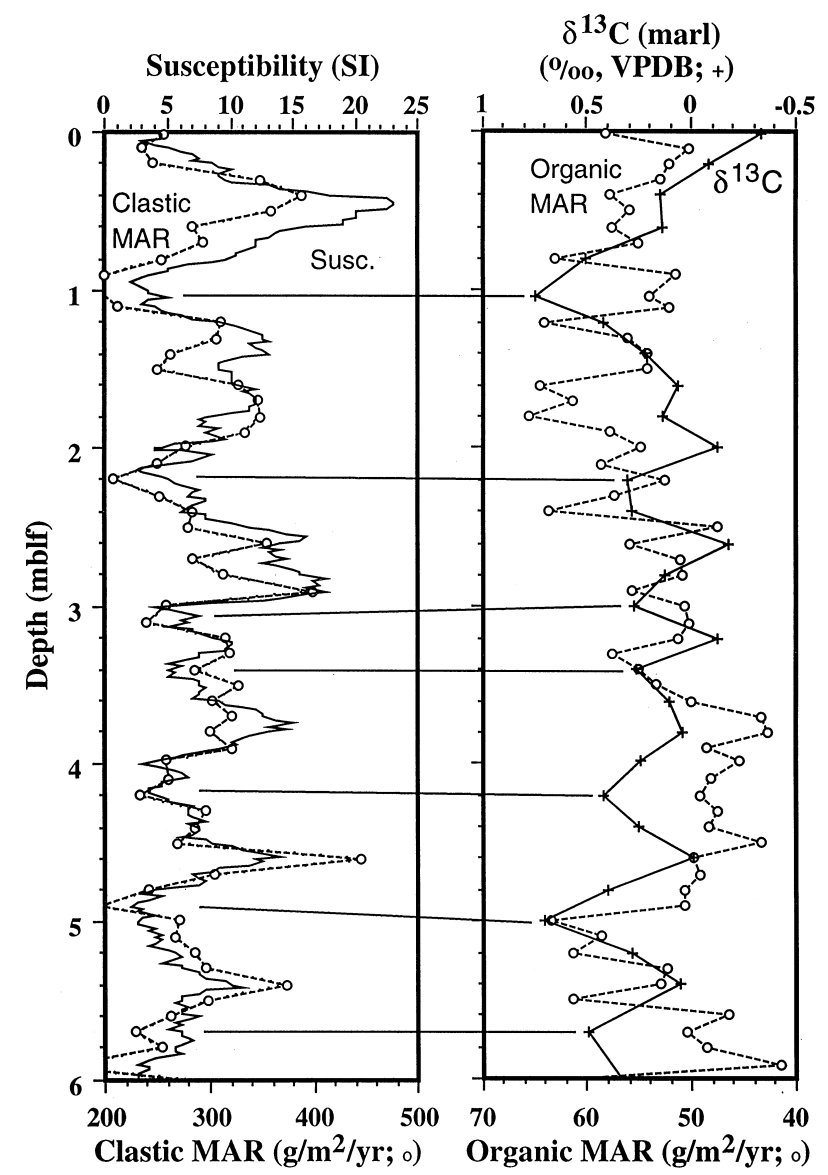

Fig. 7. Magnetic susceptibility, mass accumulation rate (MAR) of inorganic, non-carbonate material (calculated from LOI), MAR of organic matter (LOI), and isotopic composition of carbon in total carbonate (marl) versus depth for the top $6 \mathrm{~m}$ of the deep-basin core.

during this interval suggest that there were low winds, stronger stratification, and high summer productivity.

We summarized above the considerable amount of evidence from diverse proxies for aridity in the northern Great Plains during the mid-Holocene. There is now an increasing body of evidence from the sediments of several lakes for cyclic fluctuations in windiness, dustiness, and aridity in the northern Great Plains over the last several thousand years. The $1 \mathrm{~m}$ cycles in the top four meters of the Pickerel Lake magnetic susceptibility record bear a remarkable resemblance to the record of aluminum (Al) concentration in sediments deposited over the last $1550 \mathrm{yr}$ in Elk Lake (Fig. 8). Most of the sediment components that accumulated in Elk Lake during the Holocene are autochthonous or biogenic, and form distinct annual laminae (varves; Anderson, 1993; Dean, 1993; Dean et al., 1994). The main allochthonous component is detrital-clastic material, as measured by bulk-sediment concentrations of aluminum, sodium, potassium, titanium, and quartz, entering the lake mostly as eolian dust (Dean, 1993; Dean et al., 1996). Magnetic susceptibility 


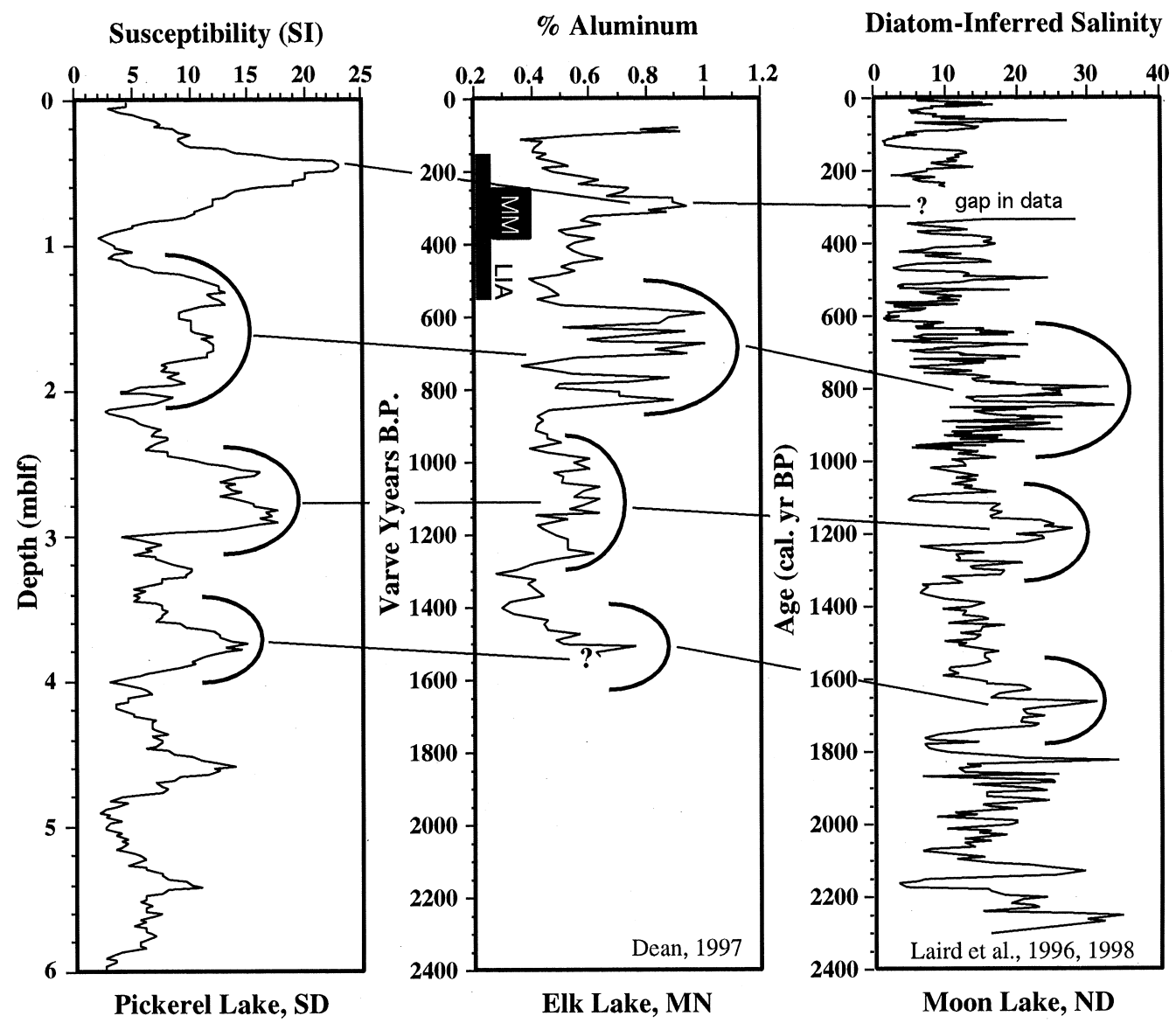

Fig. 8. Magnetic susceptibility versus depth for the top $6 \mathrm{~m}$ of sediment deposited in the deep basin of Pickerel Lake; percent aluminum in varved sediments deposited over the past $1550 \mathrm{yr}$ in Elk Lake, Clearwater County, Minnesota; and diatom-inferred salinity in sediments deposited over the past $2300 \mathrm{yr}$ in Moon Lake, North Dakota. Solid lines between plots show possible correlations of events between cores. The boxes labeled LIA and MM in the Elk Lake aluminum plot indicate the time intervals of the Little Ice Age and the Maunder minimum of sunspot activity, respectively. The Elk Lake plot is modified from Dean (1997), and the Moon Lake plot is modified from Laird et al. (1996a, 1998).

serves as an excellent proxy for detrital-clastic material throughout most of the Holocene sediment section in Elk Lake (Sprowl and Banerjee, 1993; Dean et al., 1996), except in the upper $3 \mathrm{~m}$ (approximately the last $1500 \mathrm{yr}$ ) where an abrupt increase in fine-grained magnetite may be biogenic (Sprowl and Banerjee, 1993). However, geochemical records of detrital clastics in Elk Lake sediments exhibit distinct cyclicities with dominant periodicities of 400 and $84 \mathrm{yr}$ (Dean, 1997). The most obvious Elk Lake cycles shown in Fig. 8 are three peaks or groups of peaks about $400 \mathrm{yr}$ apart. The youngest peak corresponds in time (400-200 yr ago) to the main phase of the Little Ice Age (AD 1550-1700; Lamb, 1977; LIA in Fig. 8), and the highest concentrations correspond in time to the Maunder sunspot minimum (AD 1640-1710; $\mathrm{MM}$ in Fig. 8). If the proxy of $\mathrm{Al}$ for eolian dust is correct, then the Elk Lake record suggests that northwestern Minnesota experienced windier, or at least dustier, conditions during the past $1550 \mathrm{yr}$ in cycles with periods of about 400 yr. In Fig. 8 we have drawn lines of suggested correlation between the varve-calibrated (calendar years before AD 1950) eolian record in Elk Lake and the magnetic susceptibility record in Pickerel Lake, in calibrated radiocarbon years. We suggest that the prominent susceptibility peak centered at about $250 \mathrm{cal}$. yr BP in the Pickerel Lake core corresponds to the Little Ice Age peak in Elk Lake.

However, if we accept the calibrated chronological ages from Table 1 for the top of the Pickerel Lake core, then the Pickerel Lake cycles have periodicities of about $500 \mathrm{yr}$, or about $100 \mathrm{yr}$ longer than the Elk Lake cycles. The sedimentation rate in a surface core from Pickerel Lake, determined by ${ }^{210} \mathrm{~Pb}$ measurements, is $0.48 \mathrm{~cm} / \mathrm{yr}$ (D.R. Engstrom, personal communication). At this rate, a $1 \mathrm{~m}$ cycle represents $208 \mathrm{yr}$. Because of increased erosion associated with settlement in the drainage basin of Pickerel Lake, $0.48 \mathrm{~cm} / \mathrm{yr}$ is certainly higher than the average rate of sedimentation in the lake over the last several thousand years. Within the limitations of the radiocarbon age model used, we suspect that the true sedimentation rate of the top of the Pickerel Lake core is somewhere between 0.184 and $0.48 \mathrm{~cm} / \mathrm{yr}$. Half of the 
${ }^{210} \mathrm{~Pb}$ rate, $0.24 \mathrm{~cm} / \mathrm{yr}$, is the same as the sedimentation rate used in the radiocarbon chronological model between 410 and $1306 \mathrm{~cm}$ (Fig. 2), and gives a duration of $411 \mathrm{yr}$ for a $1 \mathrm{~m}$ cycle. We conclude, therefore, that the centennial-scale periodicities of the Pickerel Lake and Elk Lake cycles are the same at about $400 \mathrm{yr}$.

There are as many as seven drought-related salinity cycles, inferred from diatom assemblages, recorded in sediments Moon Lake, North Dakota, deposited over the past $2300 \mathrm{yr}$ (Laird et al., 1996a, b, 1998). Within limits of the radiocarbon dating of the Moon Lake sediments, periods of inferred increased salinity in Moon Lake can be correlated with periods of increased eolian activity inferred from the aluminum record in Elk Lake (Fig. 8). The point is that the cycles in the Pickerel Lake and Moon Lake records are close enough in periodicity and chronology to the varve-calibrated $400 \mathrm{yr}$ cycles in the Elk Lake record to suggest that they are all recording the same cyclic fluctuations in eolian activity and aridity in the northern Great Plains.

Stabilized dune fields are abundant throughout the Northern Great Plains of the United States and Canada (Wolfe, 1997; Muhs and Wolfe, 2000). Wind velocities are sufficiently high to move sand, and the present stability of these dunes is due primarily to high moisture contents and vegetation cover. However, there have been repeated periods of active movement of these dunes during the past several thousand years. Muhs and Wolfe (2000) concluded that although these periods of dune activity are insufficiently dated, they clearly indicate fluctuations in climate, and some of these periods are probably due to droughts observed in lacustrine records.

Anderson $(1992,1993)$ found a dominant periodicity of $200 \mathrm{yr}$ in the thickness of varves deposited in Elk Lake during the mid-Holocene. He attributed these $200 \mathrm{yr}$ cycles to cycles in solar activity, with the direct connection being increased zonal winds in the troposphere driven by solar-geomagnetic disturbances. A direct connection between solar irradiance (solar constant) and weather and climate has been suggested for over $100 \mathrm{yr}$ but generally rejected by most scientists, who assume that the effect of solar variations would be small (see review by Lean and Rind, 1994). However, recent modeling studies indicate that a small decrease in total solar irradiance $(0.25 \%)$ could produce a global temperature decrease of the magnitude suggested for the Little Ice Age (Reid, 1991, 1993; Lean and Rind, 1994). Far more variable than changes in total solar irradiance are changes in amount of energy emitted as ultraviolet, extreme ultraviolet, and X-rays, and in the continuous outflow of ionized solar particles (solar wind; Evans, 1982), which controls the properties of the earth's magnetosphere. The connection between solar activity, as measured by what solar physicists refer to as "coronal mass ejections" or CMEs, and geomagnetic storms has been well documented in recent years (see reviews by
Cliver, 1994a, b, 1995). Not all CMEs are associated with chromospheric eruptions (solar flares) as was once thought, but CMEs are associated with geomagnetic storms (Cliver, 1995).

Is there a connection between geomagnetic storms and climate that might form another link (in addition to solar irradiance) between the sun and climate, with geomagnetic storms as the intermediate step? In the upper atmosphere, winds at $300 \mathrm{~km}$ as strong as $500 \mathrm{~m} / \mathrm{s}$ blowing southward over North America have been observed during times of magnetic disturbances (Evans, 1982). It is not known, however, how these upper-atmosphere winds affect the lower atmosphere (troposphere). Roberts and Olson (1973) observed that strong solar-geomagnetic disturbances in the troposphere during winter were often followed within a few days by a deepening of subpolar low-pressure systems (300 mbar troughs) over the North Pacific. Stolov and Shapiro (1974) studied the $700 \mathrm{mbar}$ heights in the northern hemisphere between 20 and $70^{\circ} \mathrm{N}$ for $33 \mathrm{~d}$ before and $66 \mathrm{~d}$ following 272 solar-geomagnetic disturbances over the period from 1947 to 1970 . They noted that the most significant response to these disturbances was a decrease in the $700 \mathrm{mbar}$ height in winter relative to the average for the same period ("climatology") four days following a disturbance. The decrease in summer was less prominent, and occurred two days following a disturbance. The decrease is greatest between 70 and $110^{\circ}$ west longitude and between 40 and $70^{\circ}$ north latitude and corresponds to an increase by as much as $7 \%$ in tropospheric westerly flow, which translates to an increase in mean zonal wind velocity of about $0.6 \mathrm{~m} / \mathrm{s}$. The Northern Great Plains lie near the center of the region where the strongest response by zonal winds has been reported (Stolov and Shapiro, 1974; see discussions by Anderson, 1992, 1993). Statistical analyses by Tinsley and Deen (1991) of $33 \mathrm{yr}$ of meteorological data show a clear correlation between the intensity of cyclonic circulation in mid-latitude oceanic regions with changes in cosmic-ray flux following geomagnetic storms.

Based on the evidence outlined above, it seems reasonable that the cycles in aridity and eolian activity over the past several thousand years recorded in the sediments of lakes in the northern Great Plains might also have a solar connection. Recently, Yu and Ito (1999) described cyclic fluctuations in the salinity of Rice Lake, North Dakota, over the past $2100 \mathrm{yr}$ based on $\mathrm{Mg} / \mathrm{Ca}$ ratios of ostracodes in the sediments. The dominant periodicities of the Rice Lake salinity cycles were 400 and $200 \mathrm{yr}$. Because these periodicities are similar to the main periodicities of solar oscillations inferred from radiocarbon production, $\mathrm{Yu}$ and Ito suggested that there might be solar forcing of drought cycles in the northern Great Plains. It seems clear that century-scale cycles in aridity and eolian activity were a dominant feature of the climate of the northern Great Plains over the past $2000 \mathrm{yr}$, possibly with a solar-geomagnetic link. 


\section{Conclusions}

The sediments at the base of the deep-basin core from Pickerel Lake that accumulated between 12 and $11 \mathrm{ka}$ consist of organic and detrital-clastic debris that probably represents the floor of a supraglacial spruce forest. An open-water environment apparently existed by about $11 \mathrm{ka}$, and rapid leaching of carbonate from calcareous glacial drift, together with increased surface-water temperatures, resulted in massive precipitation of carbonate. The carbon-isotope composition of organic matter records the transition from forest with predominantly $\mathrm{C}_{3}$ vegetation to prairie with a mixture of $\mathrm{C}_{3}$ and $\mathrm{C}_{4}$ vegetation between 11 and $6 \mathrm{ka}$. Marked increases in values of both $\delta^{18} \mathrm{O}$ and $\delta^{13} \mathrm{C}$ of carbonate over the same time interval record a change in the hydrology of Pickerel Lake with reduced flow and increased residence time. These ${ }^{18} \mathrm{O}$ - and ${ }^{13} \mathrm{C}$-enriched isotopic values probably also reflect the shift from forest to prairie vegetation and a change in source and/or seasonality of precipitation. Lower lake levels and greater erosion between 8 and $6 \mathrm{ka}$ are suggested by increased clastic influx (increased magnetic susceptibility) and by a pulse of ${ }^{18} \mathrm{O}$ - and ${ }^{13} \mathrm{C}$ enriched carbonate.

The lake and the surrounding landscape appear to have reached equilibrium by about $6 \mathrm{ka}$ because the bulk composition of the sediments (indicated by organic carbon carbonate, and magnetic susceptibility), and the isotopic composition of the organic carbon and carbonate change very little in the upper $13 \mathrm{~m}$ of the core. However, the upper $6 \mathrm{~m}$ of sediment (estimated to have been deposited over the past 2000-3000 yr) exhibit distinct meterscale cycles (estimated to represent $400-500 \mathrm{yr}$ ) in magnetic susceptibility, carbonate, organic carbon, and the isotopic composition of the organic carbon. These cycles are interpreted as recording cyclic fluctuations in the influx of detrital-clastic material, probably windborne, and possibly in organic productivity. Similar cyclic fluctuations in other proxy variables for eolian activity and aridity in the sediments of other lakes suggest that aridity cycles were a dominant part of the climate of the northern Great Plains over the past several thousand years.

\section{Acknowledgements}

We thank Nancy Bigelow, Gideon N'Gobi, Victoria Okusami, Blas Valero-Garcés and Herb Wright for helping with coring, Jim Burdett for help with the stable isotope analysis, Jeannine Honey for help with the carbon analyses, Gary Skipp for help with the X-ray diffraction analyses, and Rick Forester for many stimulating comments and discussions. This paper has benefited greatly from thoughtful reviews by Rick Forester and Dan Muhs. This research was conducted as part of a post-doctoral fellowship to A.S. at the Limnological Research Center, University of Minnesota, funded by the Swiss National Science Foundation. Additional support was provided by the US Geological Survey Global Change and Climate History Program (WED). This is contribution No. 533 of the Limnological Research Center.

\section{References}

Alley, R.A., Mayewski, P.A., Sowers, T., Stuiver, M., Taylor, K.C., Clark, P.U., 1997. Holocene climatic instability: a prominent, widespread event 8200 yr ago. Geology 25, 483-486.

Anderson, R.Y., 1992. Possible connection between surface winds, solar activity and the Earth's magnetic field. Nature 358, 51-53.

Anderson, R.Y., 1993. The varve chronometer in Elk Lake: record of climatic variability and evidence for solar-geomagnetic- ${ }^{14} \mathrm{C}$-climate connection. In: Bradbury, J.P., Dean, W.E. (Eds.), Elk Lake, Minnesota: evidence for Rapid Climate Change in the North-Central United States. Geological Society of America, Special Paper, Vol. 276, pp. 45-68.

Barber, D.C., Dyke, A.S., Hillaire-Marcel, C., Jennings, A.E., Andrews, J.T., Kerwin, M.W., Bilodeau, G., McNeely, R., Southon, J., Morehead, M.D., Gagnon, J.M., 1999. Forcing of the cold event of $8,200 \mathrm{yr}$ ago by catastrophic drainage of Laurentide lakes. Nature 400, 344-348.

Bender, M.M., 1971. Variations in the ${ }^{13} \mathrm{C} /{ }^{12} \mathrm{C}$ ratios of plants in relation to the pathway of photosynthetic carbon dioxide fixation. Phytochemistry 10, 1239-1243.

Bradbury, J.P., Dieterich-Rurup, K., 1993. Holocene diatom paleolimnology of Elk Lake, Minnesota. In: Bradbury, J.P., Dean, W.E. (Eds.), Elk Lake, Minnesota: evidence for Rapid Climate Change in the North-Central United States. Geological Society of America, Special Paper, Vol. 276, pp. 215-238.

Bradbury, J.P., Dean, W.E., Anderson, R.Y., 1993. Holocene climatic and limnologic history of the north-central United States as recorded in the varved sediments of Elk Lake, Minnesota: a synthesis. In: Bradbury, J.P., Dean, W.E. (Eds.), Elk Lake, Minnesota: evidence for Rapid Climate Change in the North-Central United States. Geological Society of America, Special Paper, Vol. 276, pp. 215-238.

Bryson, R.A., 1966. Air masses, streamlines, and the boreal forest. Geographical Bulletin 8, 228-269.

Bryson, R.A., Hare, F.K., 1974. Climates of North America. In: Landsberg, H.E. (Ed), World Survey of Climatology, Vol. 11. Elsevier, Amsterdam, 420pp.

Cerling, T.E., Quade, J., 1993. Stable carbon and oxygen isotopes in soil carbonates. In: Swart, P.K., Lohmann, K.C., McKenzie, J., Savin, S. (Eds.), Climate Change in Continental Isotopic Records. American Geophysical Union, Geophysical Monograph, Vol. 78, pp. 217-231.

Cliver, E.W., 1994a. Solar activity and geomagnetic storms. The first 40 years. EOS (Transactions of the American Geophysical Union) 75, 569-576.

Cliver, E.W., 1994b. Solar activity and geomagnetic storms. The corpuscular hypothesis. EOS (Transactions of the American Geophysical Union) 75, 609-613.

Cliver, E.W., 1995. Solar activity and geomagnetic storms. From M regions and flares to coronal holes and CMEs. EOS (Transactions of the American Geophysical Union) 76, 75-83.

Dean, W.E., 1974. Determination of carbonate and organic matter in calcareous sediments and sedimentary rocks by loss on ignition: comparison with other methods. Journal of Sedimentary Petrology $44,242-248$. 
Dean, W.E., 1993. Physical properties, mineralogy, and geochemistry of Holocene varved sediments from Elk Lake, Minnesota. In: Bradbury, J.P., and Dean, W.E. (Eds.), Elk Lake, Minnesota: evidence for Rapid Climate Change in the North-Central United State. Geological Society of America, Special Paper, Vol. 276, pp. 135-158.

Dean, W.E., 1997. Rates, timing, and cyclicity of Holocene eolian activity in north-central United States: evidence from varved lake sediments. Geology 25, 331-334.

Dean, W.E., Arthur, M.A., 1998. Geochemical expressions of cyclicity in Cretaceous pelagic limestone sequences: Niobrara Formation, Western Interior Seaway. In: Dean, W.E., Arthur, M.A. (Eds.), Stratigraphy and Paleoenvironments of the Cretaceous Western Interior Seaway, US. Society of Economic Paleontologists and Mineralogists, Concepts in Sedimentology and Paleontology, Vol. 6, pp. 227-255.

Dean, W.E., Ahlbrandt, T.S., Anderson, R.Y., Bradbury, J.P., 1996. Regional aridity in North America during the middle Holocene. The Holocene 6, 145-155.

Dean, W.E., Arthur, M.A., Claypool, G.E., 1986. Depletion of ${ }^{13} \mathrm{C}$ in Cretaceous marine organic matter: source, diagenetic, or environmental signal? Marine Geology 70, 119-157.

Dean, W.E., Bradbury, J.P., Anderson, R.Y., Bader, L.R., DieterichRurup, K., 1994. A high resolution record of climatic change in Elk Lake, Minnesota for the last 1500 years. U.S. Geological Survey, Open-File Report 94-578, 127pp.

Dean, W.E., Gorham, E., 1976. Major chemical and mineral components of profundal surface sediments in Minnesota lakes. Limnology and Oceanography 21, 259-284.

Dean, W.E., Megard, R.O., 1993. Environment of deposition of $\mathrm{CaCO}_{3}$ in Elk Lake, Minnesota. In: J.P. Bradbury, Dean, W.E. (Eds.), Elk Lake, Minnesota: evidence for Rapid Climate Change in the North-Central United States. Geological Society of America, Special Paper, Vol. 276, pp. 97-113.

Dean, W.E., Stuiver, M., 1993. Stable carbon and oxygen isotope studies of the sediments of Elk Lake, Minnesota. In: Bradbury, J.P., Dean, W.E. (Eds.), Elk Lake, Minnesota: evidence for Rapid Climate Change in the North-Central United States. Geological Society of America, Special Paper, Vol. 276. pp. 163-189.

Deines, P., 1980. The isotopic composition of reduced organic carbon. In: Fritz, P., Fontes, J.C. (Eds.), Handbook of Environmental Isotope Geochemistry, Vol. 1. The Terrestrial Environment. Elsevier, Amsterdam, pp. 329-406,

Drummond, C.N., Patterson, W.P., Walker, J.C.G., 1995. Climatic forcing of carbon-oxygen isotopic covariance in temperate-region marl lakes. Geology 23, 1031-1034.

Engleman, E.E., Jackson, L.L., Norton, D.R., Fischer, A.G., 1985. Determination of carbonate carbon in geological materials by coulometric titration. Chemical Geology 53, 125-128.

Evans, J.V., 1982. The sun's influence on earth's atmosphere and interplanetary space. Science 216, 467-473.

Fritz, S.C., 1990. Twentieth-century salinity and water-level fluctuations in Devils Lake, North Dakota: test of a diatom-based transfer function. Limnology and Oceanography 35, 1771-1781.

Fritz, S.C., 1996. Paleolimnological records of climate change in North America. Limnology and Oceanography 41, 882-889.

Fritz, S.C., Juggins, S., Batterbee, R.W., Engstrom, D.R., 1991. Reconstruction of past changes in salinity and climate using a diatombased transfer function. Nature 352, 706-708.

Fritz, S.C., Juggins, S., Batterbee, R.W., 1993. Diatom assemblages and ionic characterization of lakes of the northern Great Plains, North America: a tool for reconstructing past salinity and climate fluctuations. Canadian Journal of Fisheries and Aquatic Sciences 50, 1844-1856.

Gat, J.R., Bowser, C.J., Kendall, C., 1994. The contribution of evaporation from the Great Lakes to the continental atmosphere: estimate based on stable isotope data. Geophysical Research Letters 21, $557-560$.
Gorham, E., Dean, W.E., Sanger, J.E., 1982. The chemical composition of lakes in the north-central United States. U.S. Geological Survey, Open-File Report 82-149, 59pp.

Gorham, E., Dean, W.E., Sanger, J.E., 1983. The chemical composition of lakes in the north-central United States. Limnology and Oceanography 28, 287-301.

Haskell, B.J., Engstrom, D.R., Fritz, S.C., 1996. Late Quaternary paleohydrology in the North American Great Plains inferred from the geochemistry of endogenic carbonate and fossil ostracodes from Devils Lake. North Dakota, USA. Palaeogeography, Palaeoclimatology, and Palaeoecology 124, 179-193.

Haworth, E.Y., 1972. Diatom succession in a core from Pickerel Lake, Northeastern South Dakota. Geological Society of America, Bulletin $83,157-172$.

Hu, F.S., Wright Jr., H.E., Ito, E., Lease, K., 1997. Climatic effects if glacial Lake Agassiz in the midwestern United States during the last deglaciation. Geology 25, 207-210.

Hu, F.S., Slawinski, D., Wright Jr., H.E., Ito, E., Johnson, R.G., Kelts, K.R., McEwan, R.F., Boedigheimer, 1999. Abrupt changes in North American climate during the early Holocene times. Nature 400, 437-440.

Keen, K.L., Shane, L.C.K., 1990. A continuous record of eolian activity and vegetation change at Lake Ann, east-central Minnesota. Geological Society of America, Bulletin 102, 1646-1657.

Klitgaard-Kristensen, D., Sejrup, H.-P., Haflidason, H., Johnsen, S., Spurk, M., 1998. A regional 8200 cal. yr BP cooling event in northwest Europe, induced by final stages of the Laurentide icesheet deglaciation? Journal of Quaternary Science 13, 165-169.

Kutzbach, J.E., 1987. Model simulations of the climatic patterns during deglaciation of North America. In: Ruddiman, W.F., Wright Jr., H.E. (Eds.), North America and Adjacent Oceans during the Last Deglaciation. Geological Society of America, The Geology of North America K-3, pp. 425-446.

Laird, K.R., Fritz, S.C., Grimm, E.C., Mueller, P.G., 1996a. Centuryscale paleoclimatic reconstruction from Moon Lake, a closed-basin lake in the northern Great Plains. Limnology and Oceanography 41, 890-902.

Laird, K.R., Fritz, S.C., Maasch, K.A., Cumming, B.F., 1996b. Greater drought intensity and frequency before AD 1200 in the Northern Great Plains. USA. Nature 384, 552-554.

Laird, K.R., Fritz, S.C., Cumming, B.F., 1998. A diatom-based reconstruction of drought intensity, duration, and frequency from Moon Lake, North Dakota: a sub-decadal record of the last 2300 years. Journal of Paleolimnology 19, 161-179.

Lamb, H.H., 1977. Climate - Past, Present, and Future, Climatic History and the Future. Methuen, London, 835pp.

Lean, J., Rind, D., 1994. Solar variability: implications for global change. EOS (Transactions of the American Geophysical Union) 75, $1-7$.

Ludvigson, G.A., Wkitzke, B.J., Gonzalez, L.A., Hammond, R.H., Pocher, O.W., 1994. Sedimentology and carbonate geochemistry of concretions from the Greenhorn marine cycle (CenomanianTuronian), eastern margin of the Western Interior Seaway. In: Shurr, G.W., Ludvigson, G.A., Hammond, R.H. (Eds.), Perspectives of the eastern margin of the Cretaceous Western Interior Basin. Geological Society of America, Special Paper, Vol. 287, pp. 145-173.

McKenzie, J.A., 1985. Carbon isotopes and productivity in the lacustrine and marine Environment. In: Stumm, W. (Ed.), Chemical Processes in Lakes. Wiley, New York, pp. 99-118.

Moore, D.M., Reynolds Jr., R.C., 1989. X-ray diffraction and identification and analysis of clay minerals. Oxford University Press, Oxford, 332pp.

Muhs, D.R., 1985. Modelling the Prehistoric response to Altithermal climates on the Southern High Plains. In: Johnson, E. (Ed.), Ancient Peoples and Landscapes. Museum of Texas Tech University, Lubbock, Texas, pp. 349-368. 
Muhs, D.R., Wolfe, S.A., 2000. Sand dunes of the Northern Great Plains of Canada and the United States. Geological Survey of Canada, Bulletin, in press.

Muhs, D.R., Ager, T.A., Been, J.M., Rosenbaum, J.G., Reynolds, R.L., 2000. An evaluation of methods for identifying and interpreting buried soils in late Quaternary loess in Alaska. In: Geologic studies in Alaska by the U.S. Geological Survey. United States Geological Survey, Professional Paper, in press.

Nativ, R., Riggio, R., 1990. Precipitation in the southern high plains: meteorological and isotopic features. Journal of Geophysical Research 95, 22,559-22,564.

Radle, N., Keister, C.M., Batterbee, R.W., 1989. Diatom, pollen, and geochemical evidence for the paleosalinity of Medicine Lake, South Dakota, during the Late Wisconsin and early Holocene. Journal of Paleolimnology 2, 159-172.

Reid, G.C., 1991. Solar total irradiance variations and the global sea-surface temperature record. Journal of Geophysical Research 96, 2835.

Reid, G.C., Do solar variations change climate? EOS (Transactions of the American Geophysical Union) 74, 23.

Roberts, W.O., Olson, R.H., 1973. Geomagnetic storms and wintertime $300 \mathrm{mb}$ trough development in the North Pacific-North America area. Journal of Atmospheric Science 30, 135-140.

Rodinov, S.N., 1994. Association between winter precipitation and water level fluctuations in the Great Lakes and atmospheric circulation patterns. Journal of Climate 7, 1693-1706.

Rozanski, K., Araguás-Araguás, L., Gobfianatini, R., 1993. Isotopic patterns in modern global precipitation. In: Swart, P.K., Lohmann, K.C., McKenzie, J.A., Savin, S. (Eds.), Climate Change in Continental Isotopic Records. American Geophysical Union, Geophysical Monograph, Vol. 78, pp. 1-36.

Sanger, J.E., Hay, R.J., 1993. Fossil pigments in Holocene varved sediments in Elk Lake, Minnesota. In: Bradbury, J.P., Dean, W.E. (Eds.), Elk Lake, Minnesota: evidence for Rapid Climate Change in the North-Central United States. Geological Society of America, Special Paper, Vol. 276, pp. 181-188.

Schwalb, A., Dean, W.E., 1998. Stable isotopes and sediments from Pickerel Lake, South Dakota, USA: a 12ky record of environmental changes. Journal of Paleolimnology 20, 15-30.

Schwalb, A., Locke, S.M., Dean, W.E., 1995. Ostracode $\delta{ }^{18} \mathrm{O}$ and $\delta{ }^{13} \mathrm{C}$ evidence of Holocene environmental changes in the sediments of two Minnesota lakes. Journal of Paleolimnology 14, 281-296.

Simpkins, W.W., 1995. Isotopic composition of precipitation in central Iowa. Journal of Hydrology 172, 185-207.

Smith, A.J., 1991. Lacustrine ostracodes as paleohydrological indicators in Holocene lake records of the north-central United States. Ph.D. Dissertation, Brown University, Providence, Rhode Island, 306pp.

Smith, A.J., 1993. Lacustrine ostracodes as hydrochemical indicators in lakes of the north-central United States. Journal of Paleolimnology $8,121-134$.

Smith, A.J., Donovan, J.J., Ito, E., Engstrom, D.R., 1997. Ground-water processes controlling a prairie lake's response to middle Holocene drought. Geology 25, 391-394.

Smith, M.A, Hollander, D.J., 1999. Changes in the pattern of atmospheric circulation over central North America during the past 100 years: evidence from the oxygen-isotope record of sedimentary carbonates from Lake Mendota, Wisconsin. Geology 27, 589-592.

Sprowl, D.R., Banerjee, S.K., 1993. Geologic implications of the Elk Lake paleomagnetic record. In: Bradbury, J.P., Dean, W.E. (Eds.), Elk Lake, Minnesota: evidence for Rapid Climate Change in the North-Central United States. Geological Society of America, Special Paper, Vol. 276, pp. 159-162.

Stolov, H.L., Shapiro, R., 1974. Investigation of the responses of the general circulation at 700 mbar to solar-geomagnetic disturbance. Journal of Geophysical Research 79, 2161-2170.
Stuiver, M., 1970. Oxygen and carbon isotope ratios of fresh-water carbonates as climatic indicators. Journal of Geophysical Research $75,5247-5257$.

Stuiver, M., Reimer, P.J., 1993. Extended ${ }^{14} \mathrm{C}$ data base and revised calib $3.0{ }^{14} \mathrm{C}$ age calibration program. Radiocarbon 35 , 215-230.

Stuiver, M., Kromer, B., Becker, B., Ferguson, C.W., 1986. Radiocarbon age calibration back to 13,300 years $\mathrm{BP}$ and the ${ }^{14} \mathrm{C}$ age matching of the German oak and US bristlecone pine chronologies. Radiocarbon 28, 969-979.

Teller, J.T., 1985. Glacial Lake Agassiz and its influence on the Great Lakes. In: Karrow, P.F., Calkin, P.E. (Eds.), Quaternary Evolution of the Great Lakes. Geological Association of Canada, Special Paper, Vol. 30, pp. 1-16.

Teller, J.T., 1987. Proglacial lakes and the southern margin of the Laurentide ice sheet. In: Ruddiman, W.F., Wright Jr., H.E. (Eds.), North America and Adjacent Oceans during the Last Deglaciation. Geological Society of America, The Geology of North America K-3, pp. 39-69.

Tinsley, B.A., Deen, G.W., 1991. Apparent tropospheric response to MeV-GeV particle flux variations: a connection via electrofreezing of supercooled water in high-level clouds. Journal of Geophysical Research 96, 22,283-22,296.

Valero-Garces, B., Kelts, K.R., 1995. A sedimentary facies model for perennial and meromictic saline lakes: Holocene Medicine Lake basin. South Dakota, USA. Journal of Paleolimnology 154, 123-149.

von Grafenstein, U., Erlenkeuser, H., Müller, J., Jouzel, J., Johnsen, S., 1998. The cold event $8200 \mathrm{yr}$ ago documented in oxygen isotope records of precipitation in Europe and Greenland. Climate Dynamics $14,73-81$.

Watts, W.A., Bright, R.C., 1968. Pollen, seed, and mollusk analysis of a sediment core from Pickerel Lake, northeastern South Dakota. Geological Society of America, Bulletin 79, 855-876.

Whitlock, C., Bartlein, P.J., Watts, W.A., 1993. Vegetation history of Elk Lake. In: Bradbury, J.P., Dean, W.E. (Eds.), Elk Lake, Minnesota: evidence for Rapid Climate Change in the North-Central United States. Geological Society of America, Special Paper, Vol. 276, pp. 251-274.

Winter, T.C., 1999. Relation of streams, lakes, and wetlands to groundwater flow systems. Hydrogeology Journal 7, 28-45.

Wolfe, S.A., 1997. Impact of increased aridity on sand dune activity in the Canadian Prairies. Journal of Arid Environments 36, 421-432.

Wright Jr., H.E., 1967. A square-rod piston sampler for lake sediments. Journal of Sedimentary Petrology 37, 975-976.

Wright Jr., H.E., 1992. Patterns of Holocene climatic change in the midwestern United States. Quaternary Research 38, 129-134.

Wright Jr., H.E., 1993. History of the landscape in the Itasca region. In: Bradbury, J.P., Dean, W.E. (Eds.), Elk Lake, Minnesota: evidence for Rapid Climate Change in the North-Central United States. Geological Society of America, Special Paper, Vol. 276, pp. $7-17$.

Wright, H.E., Lease, K., Johnson, S., 1998. Glacial River Warren, Lake Pepin, and the Environmental history of southeastern Minnesota. In: Patterson, C.J., Wright Jr., H.E. (Eds.), Contributions to the Quaternary Geology of Minnesota. Minnesota Geological Survey Report of Investigations, Vol. 49, pp. 85-100.

Xia, J., Haskell, B.J., Engstom, D.R., Ito, E., 1997. Holocene climate reconstructions from tandem trace-element and stable isotope composition of ostracodes from Coldwater Lake. North Dakota, USA. Journal of Paleolimnology 17, 85-100.

Yu, Z., Ito, E., 1999. Possible solar forcing of century-scale drought frequency in the northern Great Plains. Geology 27, 263-266. 